\title{
LOSY ŚWIĄTYŃ I WSPÓLNOT RZYMSKOKATOLICKICH W OBWODZIE KAMIENIECKO-PODOLSKIM (CHMIELNICKIM) ${ }^{1}$ W LATACH 1944-1964
}

\begin{abstract}
Streszczenie
Celem artykułu jest przestawienie sowieckiej polityki wyznaniowej wobec Kościoła rzymskokatolickiego w obwodzie kamieniecko-podolskim (chmielnickim) na Ukrainie w latach 1944-1964, ze szczególnym uwzględnieniem przedsięwzięć władz państwowych ukierunkowanych na likwidację katolickich obiektów sakralnych.

Akcja masowego zamykania świątyń rozpoczęta przez Sowietów na przełomie lat 1946-1947, mimo że nie była do końca zrealizowana, przeniosła znaczne rezultaty. W 1964 r. z ponad 30 funkcjonujących po wojnie świątyń katolickich, w obwodzie kamieniecko-podolskim (chmielnickim) pozostało jedynie 11: w Gródku Podolskim, Gołuzubińcach, Mińkowcach, Manikowcach, Podleśnym Mukarowie, Derażni, Kitajgrodzie, Latyczowie, Strudze, Greczanach i Połonnem.

Pretekstem do zamykania kościołów był brak stałego duszpasterza, niewielka liczba wiernych, zły stan techniczny pomieszczeń czy też zbyt mała odległość świątyni od innych budynków sakralnych. Niekiedy powodem była np. pilna potrzeba założenia domu kultury, szkoły bądź biblioteki. Zgodnie z zarządzeniem pełnomocnika Rady ds. kultów religijnych zamknięte świątynie mogły być przeznaczone wyłącznie dla celów kulturalno-oświatowych. W rze-
\end{abstract}

* Vladyslav Rozhkov - mgr historii, doktorant Szkoły Doktorskiej, Katolicki Uniwersytet Lubelski Jana Pawła II

e-mail: vladyslavrozhkov@gmail.com

https://orcid.org/0000-0001-9577-564X

${ }^{1}$ Obwód leży w zachodniej części Ukrainy, na obszarze historycznych regionów Podola i Wołynia. Został utworzony 22 września 1937 r. Decyzją Prezydium Rady Najwyższej ZSRR z dnia 4 lutego 1954 r. zmienił nazwę z kamieniecko-podolskiego na chmielnicki. Ukaz Priezidiuma Wierchownogo Sowieta SSSR ot 4 fiewrala 1954 goda o pierieimienowanii goroda Proskurowa w gorod Chmielnickij s Kamieniec-Podolskoj obłasti w Chmielnickuju obłast, w: Sbornik zakonow SSSR i ukazow Priezidiuma Wierchownogo Sowieta SSSR. 1938 g. - ijul 1956 g., red. J. Mandelsztam, Moskwa 1956, s. 55. 
czywistości jednak wiele kościołów, zwłaszcza na wsi, przekształcanych było na magazyny gospodarcze.

W zależności od sytuacji w poszczególnych regionach zamknięte kościoły przeznaczane były na cele kulturalno-oświatowe, gospodarcze, nierzadko też ulegały dewastacji. W świątyniach przejętych przez władze państwowe natychmiast zdejmowano krzyże. By zatrzeć sakralny charakter budynków, rozbierano również wieże kościelne i deformowano fasady świątyń.

Słowa kluczowe: religia w ZSRR; Kościół rzymskokatolicki; Podole; świątynie katolickie; Kamieniec Podolski; Chmielnicki

\author{
$* * * * *$ \\ Dla ludności polskiej w Rosji i na dawnych Kresach Wschodnich \\ kościoły stanowiły bardzo drogi symbol więzi z kulturą polską \\ oraz niesłychanie ważne, psychologiczne i moralne oparcie \\ w dążeniu do zachowania własnej tożsamości narodowej (...). \\ Dlatego Polacy zdobywali się na wielkie ofiary, \\ byle tylko uchronić je od zamknięcia. \\ Władze sowieckie doskonale zdawały sobie z tego sprawę \\ i tym bardziej dążyły do ich likwidacji ${ }^{2}$.
}

Objęcie władzy przez bolszewików w 1917 r. dało początek ponad siedemdziesięcioletnim prześladowaniom Kościoła, uważanego za niebezpiecznego wroga nowego ładu. Zgodnie z założeniami ideologii komunistycznej religia postrzegana była jako swoiste otumanienie, prowadzące do uległości wobec wyzysku, utrudniające podburzenie mas do walki klasowej. Za niemal najgroźniejszego wroga nowego ładu uznano Kościół katolicki, który w opinii władz radzieckich był najsilniejszym ideologicznym fundamentem imperializmu wśród wszystkich ówczesnych instytucji wyznaniowych. W zwalczaniu Kościoła władze sowieckie wykorzystywały różne metody, wśród których miała miejsce fizyczna eliminacja duchowieństwa i najbardziej gorliwych wiernych ${ }^{3}$.

W następstwie konsekwentnie wcielanej przez komunistów kampanii antyreligijnej już w 1937 r. Kościół katolicki w sowieckiej Ukrainie praktycznie przestał funkcjonować. Nie było żadnego księdza, który by mógł spełniać posługę duszpasterską, a wszystkie kościoły i kaplice zostały zamknięte i przerobione na kluby, kina, domy kultury, składy zboża, warsztaty mechaniczne, fabryki, archiwa lub zdewastowane. Praktyczna możliwość odzyskania świątyń oraz odrodzenia życia religijnego pojawiła się u dopiero z wkroczeniem na Ukrainę wojsk niemieckich w $1941 \mathrm{r}^{4}{ }^{4}$ Wtedy też na terenie obwodu kamieniecko-podolskiego dzięki stara-

${ }^{2}$ Cyt. za: R. Dzwonkowski, Z historii Kościoła katolickiego w ZSRS 1917-1991: pogadanki w Radiu Watykańskim, Ząbki 2005, s. 143-144.

${ }^{3}$ R. Dzwonkowski, Religia i Kościót katolicki w ZSRS oraz w krajach i na ziemiach okupowanych 1917-1991: kronika, Lublin 2010, s. 8.

${ }^{4}$ J. Szymański, Kościót katolicki na Podolu. Obwód winnicki 1941-1964, Lublin 2003, s. 32. 
niom wiernych udało się otworzyć 18 kościołów, w 1942 r. - 10, w 1943 r. - 1 i w 1944 r. $-2^{5}$.

Wiosną 1944 r. obwód kamieniecko-podolski został ponownie zajęty przez Sowietów. Władze państwowe ponownie przystąpiły do stopniowego niszczenia odradzającego się Kościoła katolickiego. Tworząc pozory normalizacji życia religijnego, odeszły od metod wojowniczego ateizmu z lat 1920-1930. Stworzyły możliwości rejestracji wspólnot religijnych. W celu uzyskania rejestracji każda ze wspólnot miała spełnić szereg warunków, m.in. złożyć protokoły wyboru członków komitetów parafialnych (tzw. dwadcatek) i komisji rewizyjnych oraz posiadać pomieszczenie przystosowane do praktyk religijnych ${ }^{6}$.

Budynki sakralne i przedmioty kultu, w świetle ustawodawstwa sowieckiego uważane były za własność państwową, zatem aby otrzymać dostęp do świątyni i jej wyposażenia, każda wspólnota religijna musiała podpisać umowę z Komitetem Wykonawczym, na mocy której zobowiązywała się dbać o powierzone jej dobra materialne, udostępniać je przedstawicielom Rady deputowanych i władz wyznaniowych oraz wykorzystywać je wyłączne do celów religijnych?

Proces rejestracji wspólnot religijnych i otwierania parafii regulowały postanowienie O porządku otwierania budynków kultu religijnego z dnia 19 listopada 1944 r. oraz Instrukcja dla petnomocników z lutego $1945 r r^{8}$ Obydwa dokumenty miały tajny charakter i przeznaczone były wyłącznie do użytku służbowego pracowników Rady ds. kultów religijnych .

Rejestracja wspólnot katolickich napotykała na różne trudności natury formalnej. Tajne rozporządzenia zalecały pełnomocnikom

${ }^{5}$ Archiwum Państwowe Obwodu Chmielnickiego (dalej: APOCh), Ispołnitielnyj komitiet Kamieniec-Podolskogo obłastnogo Sowieta dieputatow trudiaszczichsia, fund. P-338, op. 9, spr. 1, Informacyonnyj otcziot Upołnomocziennogo Sowieta po diełam rieligioznych kultow pri SNK SSSR po Kamieniec-Podolskoj obłasti za wriemia s 10 I po 1 XII 1945 goda, 2 XII 1945, k. 32.

${ }^{6}$ Szymański, Kościót katolicki na Podolu, s. 41.

${ }^{7}$ APOCh, Sowiet po diełam rieligii pri Sowietie Ministrow Ukrainy. Upołnomocziennyj Sowieta po diełam religii pri Kabinietie Ministrow Ukrainy, fund. P-6416, op. 1, spr. 43, Tipowoj dogowor, 20 VIII 1948, k. 123-124.

${ }^{8}$ Archiwum Państwowe Obwodu Iwano-Frankowskiego (dalej: APOIF), Upołnomocziennyj Sowieta po diełam rieligioznych kultow pri ispołkomie Iwano-Frankowskogo obłastnogo Sowieta dieputatow trudiaszczichsia, fund. P-388, op. 1, spr. 1, O poriadkie otkrytija molitwiennych zdanij rieligioznych kultow, 19 XI 1944, k. 68-70; APOIF, Upołnomocziennyj Sowieta po diełam rieligioznych kultow pri ispołkomie Iwano-Frankowskogo obłastnogo Sowieta dieputatow trudiaszczichsia, fund. P-388, op. 1, spr. 1, Upołnomocziennomu Sowieta po diełam rieligioznych kultow pri SNK SSSR po Ukrainskoj SSR t. Wilchowyj P.A., 14 II 1945, k. 40; O. Łysenko, Derżawa i religijni konfesiji w Ukrajini (1943-1945), w: Aktualni probłemy witczyznianoji istorii XX st. Zbirnyk naukowych prac pryswiaczenyj pamjati akad. NAN Ukrajiny Jurija Jurijowycza Kondufora, t. 2, Kijów 2004, s. 160.

${ }^{9}$ W. Rosowski, Kościót katolicki na terenie Ukraińskiej Socjalistycznej Republiki Radzieckiej po 1945 r., w: Kościoły chrześcijańskie w systemach totalitarnych, red. J. Kłaczkow, W. Rozynkowski, Toruń 2012, s. 666; Szymański, Kościót katolicki na Podolu, s. 125-128. 
nie rejestrować wspólnot katolickich w wypadkach, gdy w promieniu dwudziestu kilometrów funkcjonował już kościół, albo w sytuacji, gdy liczba wiernych nie przekraczała tysiąca osób. Działające już parafie, które nie spełniały tych warunków, należało rozwiązać jako politycznie szkodliwe organizacje kościelne ${ }^{10}$.

O ile w latach 1945-1946 na terenie sowieckiej Ukrainy liczba zarejestrowanych wspólnot religijnych wzrastała, to już w następnych latach zaczął się proces odwrotny - zamknięcia świątyń i wyrejestrowania wspólnot ${ }^{11}$. W sprawozdaniu za drugi kwartał 1947 r. pełnomocnik Rady ds. kultów religijnych w USRR Petro Wilchowyj, informując swoich przełożonych o sytuacji religijnej na Ukrainie, napisał: „usiłujemy ograniczyć ilość wspólnot religijnych rozsiewających propagandę religijno-mistyczną wśród społeczeństwa, by nie dopuścić do sztucznego wzmocnienia wspólnot"12. W wyniku tych działań w latach 1947-1961 na Ukrainie zamknięto 113 świątyń rzymskokatolickich ${ }^{13}$. Akcja zamykania świątyń przyniosła duże rezultaty. Dotyczyło to przede wszystkim zachodnich regionów Ukrainy, gdzie wskutek depolonizacji ludność katolicka pozostała głównie w miastach ${ }^{14}$.

Powodem zamykania kościołów była niewielka liczba wiernych, brak stałego duszpasterza, zbyt mała odległość świątyni od innych kościołów, zły stan techniczny pomieszczeń sakralnych ${ }^{15}$. Władzom wystarczał często pretekst, np. pilna potrzeba założenia domu kultury, biblioteki czy szkoły, aby zlikwidować kościół $1^{16}$.

Zgodnie z zarządzeniem pełnomocnika Rady ds. kultów religijnych pomieszczenia zamkniętych świątyń mogły być przeznaczone wyłącznie do celów kultu-

${ }^{10}$ W. Osadczy, Wierzyli wbrew nadziei. Z dziejów przetrwania Kościoła tacińskiego na Ukrainie radzieckiej w okresie powojennym, „Ethos”, (2001) nr 53-54, s. 156; tenże, Katolycka Cerkwa w Ukrajini. Istorycznyj narys, Lublin 2001, s. 63.

${ }^{11}$ Rosowski, Kościół katolicki na terenie Ukraińskiej Socjalistycznej Republiki Radzieckiej, s. 666 .

${ }^{12}$ Szymański, Kościół katolicki na Podolu, s. 242-243.

${ }^{13}$ Centralne Archiwum Państwowe Społecznych Organizacji Ukrainy (dalej: CAPSOU), Centalnyj komitet Komunistycznoji Partiji Ukrajiny, fund. 1, op. 23, spr. 5069, Informacyonnyj otcziot o rabotie Upołnomocziennogo Sowieta po diełam rieligioznych kultow pri Sowietie Ministrow SSSR po Ukrainskoj SSR za apriel-ijuń 1948, 10 IX 1948, k. 249; CAPSOU, Centalnyj komitet Komunistycznoji Partiji Ukrajiny, fund. 1, op. 27, spr. 4927, W Centalnyj Komitet KP Ukrajiny, 9 IX 1959, k. 263; Szymański, Kościót katolicki na Podolu, s. 356.

${ }^{14}$ Osadczy, Wierzyli wbrew nadziei, s. 159.

${ }^{15}$ APOCh, Ispołnitielnyj komitiet Kamieniec-Podolskogo obłastnogo Sowieta dieputatow trudiaszczichsia, fund. P-338, op. 9, spr. 14, Spiec'zapiska o naliczii rimsko-katoliczieskich obszczin i namiecziajemyje mieroprijatija po otsieleniju molitwiennych domow /kostiołow, kaplic/, rospusku i sniatiju s riegistracyi obszczin etogo kulta, 28 VIII 1949, k. 64-95.

${ }^{16}$ Osadczy, Wierzyli wbrew nadziei, s. 159; tenże, Kościół katolicki na Ukrainie wobec represji sowieckich, w: Represje wobec Kościoła w krajach Bloku Wschodnigo. Komuniści przeciw religii po 1944 roku, red. J. Marecki, Kraków 2011, s. 83-91; R. Dzwonkowski, Za wschodnia granica 19171993. O Polakach i Kościele $w$ dawnym ZSRR z Romanem Dzwonkowskim rozmawia Jan Pałyga, Warszawa 1993, s. 223. 
ralno-oświatowych. W rzeczywistości jednak wiele kościołów, zwłaszcza na wsi, przekształcano na magazyny gospodarcze ${ }^{17}$.

Tabela 1. Wykorzystanie niektórych zabudowań pokościelnych w obwodzie kamieniecko-podolskim (chmielnickim)

\begin{tabular}{|c|c|}
\hline Miejscowość & Wykorzystano jako \\
\hline Tarnoruda & Magazyn gospodarczy \\
\hline Wińkowce & Magazyn gospodarczy \\
\hline Krasiłów & Magazyn gospodarczy \\
\hline Kołybań & Magazyn gospodarczy \\
\hline Tynna & Rozebrany na cegły \\
\hline Wołkowce & Rozebrany na cegły \\
\hline Sołobkowce & Zdewastowany \\
\hline
\end{tabular}

Źródło: opracowanie własne na podstawie APOCh, Ispołnitielnyj komitiet Kamieniec-Podolskogo obłastnogo Sowieta dieputatow trudiaszczichsia, fund. P-338, op. 9, spr. 28, Ispolzowanije pomieszczienij zakrytych w pieriod 1946-1953 g.g. pomieszczienij kostiołow i drugich molitwiennych domow/ kromie prawosławnoj cerkwi/ po Kamieniec-Podolskoj obłasti, 16 I 1954, k. 8-10.

\section{Wykres 1. Liczba zarejestrowanych wspólnot rzymskokatolickich w obwodzie kamieniecko-podolskim (chmielnickim) w latach 1945-1964}

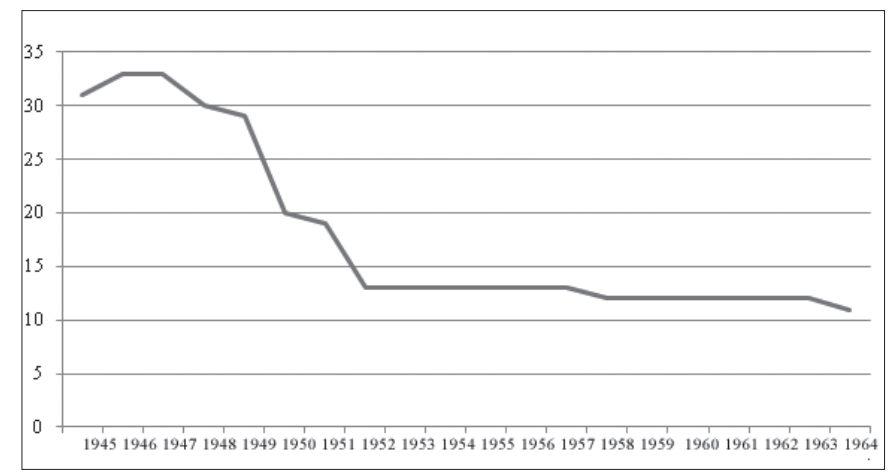

Źródło: opracowanie własne na podstawie: źródeł archiwalnych (zob. Bibliografia).

\section{Bebechy}

Kaplica z Bebechach została wzniesiona w 1900 r. W kwietniu 1945 r. obwodowy pełnomocnik Rady ds. kultów religijnych zarejestrował w tej miejscowości wspólnotę katolicką. W listopadzie 1955 r. decyzją władz obwodowych wspólno-

\footnotetext{
${ }^{17}$ Osadczy, Wierzyli wbrew nadziei, s. 160.
} 
ta została pozbawiona rejestracji. Kaplica przekazano na potrzeby kołchozu, po pewnym czasie urządzono tam elektrownię ${ }^{18}$.

\section{Berezdów}

Kościół pw. Niepokalanego Poczęcia Najświętszej Maryi Panny w Berezdowie został ufundowany w $1756 \mathrm{r} .{ }^{19} \mathrm{~W} 1935 \mathrm{r}$. decyzją władz sowieckich świątynia została zamknięta i przerobiona na klub. W 1941 r. niemieckie władze okupacyjne przekazały kościół prawosławnym. Niedługo jednak świątynia została ponownie zamknięta, a po wkroczeniu Armii Czerwonej wykorzystywana była jako spichlerz. W styczniu 1946 r. katolicy z Berezdowa zwrócili się do pełnomocnika Rady ds. kultów religijnych w obwodzie kamieniecko-podolskim z prośbą o otwarcie kościoła. Jednak władze państwowe postanowiły świątyni nie oddawać i przekształciły ją na klub ${ }^{20}$.

\section{Czercze}

Kościół w Czerczu wzniesiony został w 1637 r. z fundacji bpa kamienieckiego Pawła Piaseckiego ${ }^{21}$. Po włączeniu Podola do ZSRR kościół w Czerczu przejęty został przez władze państwowe. W okresie okupacji niemieckiej wierni odzyskali kościół i zaczęli wykorzystywać go do praktyk religijnych. W 1945 r. wspólnota katolicka w Czerczu została oficjalnie zarejestrowana przez pełnomocnika Rady ds. kultów religijnych. Według postanowienia władz obwodowych w 1949 r. wspólnota katolicka w Czerczu została wyrejestrowana, a świątynia przeznaczona na dom kultury ${ }^{22}$.

${ }^{18}$ APOCh, Ispołnitielnyj komitiet Chmielnickogo obłastnogo Sowieta dieputatow trudiaszczichsia, fund. P-338, op. 9, spr. 28, Rieszenije o sniatii s riegistracyi katoliczieskogo rieligioznogo obszcziestwa w s. Biebiechi, Wińkowieckogo rajona i pieriedaczie zdanija kaplicy etogo obszcziestwa dla nużd kołchoza im. Kaganowicza, 22 XI 1955, k. 217-219.

${ }^{19}$ Berezdów, w: Słownik geograficzny Królestwa Polskiego i innych krajów słowiańskich, red. F. Sulimierski, B. Chlebowski, W. Walewski, t. 1, Warszawa 1880, s. 141.

${ }^{20}$ APOCh, Ispołnitielnyj komitiet Chmielnickogo obłastnogo Sowieta dieputatow trudiaszczichsia, fund. P-338, op. 15, spr. 1909, Do obłasnogo Wykonawczowgo Komitetu rieligioznych kultow tow. Grieczkina ot Bieriezdowskich parachijan, brak daty, k. 262; APOCh, Ispołnitielnyj komitiet Chmielnickogo obłastnogo Sowieta dieputatow trudiaszczichsia, fund. P-338, op. 15, spr. 1909, Upołnomocziennomu Sowieta po diełam rieligioznych kultow pri Sowietie Ministrow SSSR po Kamieniec-Podolskoj obłasti tow. Sierdiuczienko, 1 III 1951, k. 265; APOCh, Ispołnitielnyj komitiet Chmielnickogo obłastnogo Sowieta dieputatow trudiaszczichsia, fund. P-338, op. 15, spr. 1909, Priedsiedatielu ispołkoma Bieriezdowskogo rajonnogo Sowieta dieputatow trudiaszczichsia tow. Bondar P. F., 16 II 1951, k. 266; O. Pasiecznik, Rimo-katoliczieskije obszcziny w Kamieniec -Podolskoj (Chmielnickoj) obłasti USRR (1945-1953), w: Represiji proty polakiw ta inszych nacionalnostej na Podilli. Rol i misce w istoriji kraju, red. I. Jaszczuk, Chmielnicki 2016, s. 87-88.

${ }^{21}$ V. Rożkow, Ksiadz Władystaw Wanags (1931-2001) - obrońca Kościoła na Podolu, Biały Dunajec-Ostróg, s. 71; Czercze, w: Słownik geograficzny, t. 1, Warszawa 1880, s. 797; Schematyzm Kamjanec-Podilskoji dijeceziji, Kamieniec-Podolski 2005, s. 93.

${ }^{22}$ APOCh, Ispołnitielnyj komitiet Kamieniec-Podolskogo obłastnogo Sowieta dieputatow trudiaszczichsia, fund. P-338, op. 9, spr. 14, Spiec'zapiska o naliczii rimsko-katoliczieskich obszczin i namiecziajemyje mieroprijatija po otsieleniju molitwiennych domow /kostiołow, kaplic/, rospusku 


\section{Czarny Ostrów}

Kościół w Czarnym Ostrowie został ufundowany w 1556 r. W roku 1815 wzniesiono nową świątynię pw. Wniebowzięcia Najświętszej Maryi Panny. W 1924 r. decyzją władz sowieckich kościół został zamknięty. Podczas tzw. wielkiej wojny ojczyźnianej 1941-1945 kościół powrócił do katolików. Przez pewien czas Niemcy przetrzymywali w świątyni jeńców sowieckich. Po zakończeniu wojny kościół wykorzystywano jako magazyn, sklep, a następnie jako klub i bibliotekę 23 .

\section{Derażnia}

Fundacja katolickiej parafii w Derażni datowana jest na rok 1736. W 1840 r. w miejsce dawnej świątyni drewnianej wzniesiono nowy kościół murowany ${ }^{24}$. W latach 30. XX wieku kościół został zburzony przez Sowietów. W 1936 r. zamknięto także kaplicę cmentarną. Po kilku latach przekształcono ją na magazyn nawozu. W okresie wojny niemiecko-sowieckiej w kaplicy derażniańskiej ponownie zaczęto odprawiać nabożeństwa. W 1945 r. obwodowy pełnomocnik na wniosek wiernych zarejestrował wspólnotę katolicką w Derażni²5.

\section{Felsztyn (Gwardziejsk)}

Drewniany kościół w Felsztynie wniesiono pod koniec XVI w. W 1763 r. w miejscu zniszczonej świątyni wystawiono murowany kościół pw. św. Wojciecha ${ }^{26}$. Po

i sniatiju s riegistracyi obszczin etogo kulta, 28 VIII 1949, k. 89; APOCh, Ispołnitielnyj komitiet Chmielnickogo obłastnogo Sowieta dieputatow trudiaszczichsia, fund. P-338, op. 15, spr. 1907, Sprawka, 26 VII 1949, k. 345; APOCh, Ispołnitielnyj komitiet Chmielnickogo obłastnogo Sowieta dieputatow trudiaszczichsia, fund. P-338, op. 15, spr. 1907, Sprawka, 29 VII 1949, k. 346; APOCh, Ispołnitielnyj komitiet Chmielnickogo obłastnogo Sowieta dieputatow trudiaszczichsia, fund. P-338, op. 15, spr. 1907, Akt, 29 VII 1949, k. 347; APOCh, Ispołnitielnyj komitiet Chmielnickogo obłastnogo Sowieta dieputatow trudiaszczichsia, fund. P-338, op. 15, spr. 1907, Sprawka, 29 VII 1949, k. 348; APOCh, Ispołnitielnyj komitiet Chmielnickogo obłastnogo Sowieta dieputatow trudiaszczichsia, fund. P-338, op. 15, spr. 1907, Zakluczienie, 2 IX 1949, k. 353-354; APOCh, Ispołnitielnyj komitiet Chmielnickogo obłastnogo Sowieta dieputatow trudiaszczichsia, fund. P-338, op. 15, spr. 1907, Rieszenije Ispołnitielnogo Komitieta Kamieniec-Podolskogo Obłastnogo Sowieta dieputatow trudiaszczichsia, 20 X 1949, k. 355; APOCh, Ispołnitielnyj komitiet Chmielnickogo obłastnogo Sowieta dieputatow trudiaszczichsia, fund. P-338, op. 15, spr. 1907, Rieszenije Ispołnitielnogo Komitieta Kamieniec-Podolskogo Obłastnogo Sowieta dieputatow trudiaszczichsia, 22 X 1949, k. 359.

${ }^{23}$ Pasiecznik, Rimo-katoliczieskije obszcziny, s. 110; Schematyzm Kamjanec-Podilskoji dijeceziji, s. 206.

${ }^{24}$ Derażnia, w: Stownik geograficzny, t. 1, Warszawa 1880, s. 958-959.

${ }^{25}$ APOCh, Ispołnitielnyj komitiet Kamieniec-Podolskogo obłastnogo Sowieta dieputatow trudiaszczichsia, fund. P-338, op. 9, spr. 14, Spiec'zapiska o naliczii rimsko-katoliczieskich obszczin i namiecziajemyje mieroprijatija po otsieleniju molitwiennych domow /kostiołow, kaplic/, rospusku i sniatiju s riegistracyi obszczin etogo kulta, 28 VIII 1949, k. 74.

${ }^{26}$ Felsztyn, w: Stownik geograficzny, t. 2, Warszawa 1881, s. 381-382; O. Pasiecznik, Rimokatoliczieskije obszczin, s. 105-106; APOCh, Podolskaja duchownaja rimo-katoliczieskaja konsistorija, fund. 685, op. 2, spr. 58, Opis Fulsztinskoj Rimsko Katoliczieskoj Prichodskoj Cerkwi Sosto- 
włączeniu Podola do ZSRR kościół felsztyński przerobiono na warsztat i magazyn gorzelni. Po pewnym zaś czasie w świątyni otwarto dom kultury. Podczas okupacji niemieckiej kościół w Felsztynie zwrócono katolikom. W latach 19441949 część kościoła była wykorzystywana jako magazyn, a w pozostałej odprawiano nabożeństwa. W 1950 r. wspólnota katolicka została wyrejestrowana. Decyzją miejscowych władz kościół pw. św. Wojciecha w Felsztynie miał być przerobiony na dom kultury ${ }^{27}$. Jednak w świątyni urządzono magazyn nawozów sztucznych i sprzętu brygady traktorowej. Nawozy i detergenty szybko zniszczyły ściany i polichromię, a po pewnym czasie destrukcji uległy organy. Wiernym, którzy w tajemnicy gromadzili się na modlitwę w domu jednej z parafianek, udało się uratować niektóre elementy wyposażenia kościoła, m.in. obraz Matki Bożej i krzyż $\dot{z}^{28}$.

\section{Gołuzubińce}

Kaplica cmentarna w Gołuzubińcach została wzniesiona w $1827 \mathrm{r}^{29}$. W $1935 \mathrm{r}$. decyzją władz sowieckich świątynia została zamknięta i przekształcona na klub. Podczas okupacji niemieckiej miejscowi katolicy odzyskali budynek i w kaplicy

jaszcziej w Kamieniec Podolskoj Jeparchii Proskurowskogo diekanata w miestieczkie Fulsztin, 1850 r., k. 120.

${ }^{27}$ F. Stara, Moji spogady pro mij ridnyj Felsztyn i kostioł swiatogo Wojcecha, „Studia Catholica Podoliae", (2014-2015) nr 8-9, s. 565-585. APOCh, Ispołnitielnyj komitiet Kamieniec-Podolskogo obłastnogo Sowieta dieputatow trudiaszczichsia, fund. P-338, op. 9, spr. 14, Spiec'zapiska o naliczii rimsko-katoliczieskich obszczin i namiecziajemyje mieroprijatija po otsieleniju molitwiennych domow /kostiołow, kaplic/, rospusku i sniatiju s riegistracyi obszczin etogo kulta, 28 VIII 1949, k. 92; APOCh, Ispołnitielnyj komitiet Kamieniec-Podolskogo obłastnogo Sowieta dieputatow trudiaszczichsia, fund. P-338, op. 15, spr. 1910, Sprawka o riegistracyi rieligioznogo obszcziestwa, 29 VI 1945, k. 345; APOCh, Ispołnitielnyj komitiet Kamieniec-Podolskogo obłastnogo Sowieta dieputatow trudiaszczichsia, fund. P-338, op. 15, spr. 1910, Upołnomocziennomu Sowieta po diełam rieligioznych kultow pri Sowietie Ministrow SSSR po Kamieniec-Podolskoj obłasti tow. Sierdiuczienko, 12 IV 1950, k. 350; APOCh, Ispołnitielnyj komitiet Kamieniec-Podolskogo obłastnogo Sowieta dieputatow trudiaszczichsia, fund. P-338, op. 15, spr. 1910, Upołnomocziennomu Sowieta po diełam rieligioznych kultow pri Sowietie Ministrow SSSR po Kamieniec-Podolskoj obłasti tow. Sierdiuczienko, 12 IV 1950, k. 350-351; APOCh, Ispołnitielnyj komitiet Kamieniec-Podolskogo obłastnogo Sowieta dieputatow trudiaszczichsia, fund. P-338, op. 15, spr. 1910, Rieszenije Ispołnitielnogo Komitieta Kamieniec-Podolskogo Obłastnogo Sowieta dieputatow trudiaszczichsia, 12 IV 1950, k. 352; APOCh, Ispołnitielnyj komitiet Kamieniec-Podolskogo obłastnogo Sowieta dieputatow trudiaszczichsia, fund. P-338, op. 15, spr. 1910, Upołnomocziennomu Sowieta po diełam rieligioznych kultow pri Sowietie Ministrow SSSR po Kamieniec-Podolskoj obłasti tow. Sierdiuczienko, 12 IV 1950, k. 353-354; APOCh, Ispołnitielnyj komitiet Kamieniec-Podolskogo obłastnogo Sowieta dieputatow trudiaszczichsia, fund. P-338, op. 15, spr. 1910, Akt, 12 IV 1950, k. 356; APOCh, Ispołnitielnyj komitiet Kamieniec-Podolskogo obłastnogo Sowieta dieputatow trudiaszczichsia, fund. P-338, op. 15, spr. 1910, Zakluczienije, 22 IV 1950, k. 375.

${ }^{28}$ D. Antoniuk, Felsztyn na Podolu, https://kuriergalicyjski.com/rozmaitosci/3853-felsztyn-na -podolu (dostęp: 06.05.2019).

${ }^{29}$ Pasiecznik, Rimo-katoliczieskije obszcziny, s. 91. 
odbywały się nabożeństwa. W marcu 1945 r. władze sowieckie zarejestrowały katolicką wspólnotę w Gołuzubińcach ${ }^{30}$.

\section{Greczany}

Kaplica rzymskokatolicka w Greczanach została wzniesiona w 1926 r. W latach 30. XX wieku została zamknięta i przekazana na potrzeby kołchozu. Podczas okupacji niemieckiej w kaplicy ponownie zaczęto odprawiać nabożeństwa. W kwietniu 1945 r. Rada ds. kultów religijnych zarejestrowała wspólnotę katolicką w Greczanach ${ }^{31}$. Kaplica greczańska funkcjonowała przez cały okres władzy sowieckiej. Po II wojnie światowej w parafii greczańskiej posługę duszpasterską pełnili księża: Juliusz Kowalski, Antoni Borysowicz, Andrzej Gładysiewicz, Jan Olszański, Juozas Budrevičius, Wincenty Witko, Tadeusz Hoppe, Bronisław Mirecki, Vytautas Merkys SJ.

\section{Gródek Podolski}

Od końca XVIII wieku w Gródku Podolskim funkcjonowały dwa kościoły: pw. śś. Anny i Antoniego oraz św. Stanisława Biskupa i Męczennika. W 1935 r. świątynie zostały zamknięte przez władze sowieckie i zdewastowane. Zamknięto także wybudowaną w $1845 \mathrm{r}$. kaplicę na cmentarzu. Podczas okupacji niemieckiej w kaplicy cmentarnej zaczęto ponownie odprawiać nabożeństwa ${ }^{32}$. W kwietniu 1945 r. obwodowy pełnomocnik Rady ds. kultów religijnych zarejestrował wspólnotę katolicką w Gródku Podolskim ${ }^{33}$. Mimo usilnych starań władz gródecka kaplica otwarta była przez cały okres sowiecki ${ }^{34}$. Proboszczami parafii gródeckiej po II wojnie światowej byli kolejno: ks. Jan Olszański, ks. Franciszek Karasiewicz, ks. Władysław Wanags MIC.

${ }^{30} \mathrm{APOCh}$, Ispołnitielnyj komitiet Kamieniec-Podolskogo obłastnogo Sowieta dieputatow trudiaszczichsia, fund. P-338, op. 9, spr. 14, Informacyonnyj otcziot o rabotie Upołnomocziennogo Sowieta po diełam rieligioznych kultow pri Sowietie Ministrow SSSR, pri Kamieniec-Podolskom obł'ispołkomie za III kw. 1949 g., 22 X 1949, k. 106.

${ }^{31}$ APOCh, Ispołnitielnyj komitiet Kamieniec-Podolskogo obłastnogo Sowieta dieputatow trudiaszczichsia, fund. P-338, op. 9, spr. 14, Spiec'zapiska o naliczii rimsko-katoliczieskich obszczin i namiecziajemyje mieroprijatija po otsieleniju molitwiennych domow /kostiołow, kaplic/, rospusku i sniatiju s riegistracyi obszczin etogo kulta, 28 VIII 1949, k. 85.

${ }^{32}$ Rożkow, Ksiądz Władysław Wanags, s. 25.

${ }^{33}$ APOCh, Ispołnitielnyj komitiet Kamieniec-Podolskogo obłastnogo Sowieta dieputatow trudiaszczichsia, fund. P-338, op. 9, spr. 14, Informacyonnyj otcziot o rabotie Upołnomocziennogo Sowieta po diełam rieligioznych kultow pri Sowietie Ministrow SSSR, pri Kamieniec-Podolskom obł'ispołkomie za III kw. 1949 g., 22 X 1949, k. 108.

${ }^{34}$ APOCh, Sowiet po diełam rieligii pri Sowietie Ministrow Ukrainy. Upołnomocziennyj Sowieta po diełam religii pri Kabinietie Ministrow Ukrainy, fund. P-6416, op. 1, spr. 10, O zajawlenii ispoł'organa RKC g. Gorodok, 26 IV 1990, k.19-20; Rożkow, Ksiądz Władysław Wanags, s. 25-52; M. Biletska, Ks. Władystaw Wanags MIC i jego postuga na Podolu w latach 1977-2001, „Archiwa, Biblioteki i Muzea Kościelne”, 107 (2017) s. 41-50. 


\section{Kamieniec-Podolski}

Katedra pw. św. Piotra i Pawła została ufundowana ok. 1430 r. Po 1483 r. rozpoczęto budowę murowanej świątyni. W 1672 r. katedra kamieniecka została zamieniona przez Turków na meczet sułtański, najważniejsze miejsce kultu muzułmańskiego w mieście. Pamiątką tego jest jeden z dwóch minaretów, pozostawiony przy fasadzie zachodniej katedry zgodnie z traktatem pokojowym z 1699 r. W połowie XVIII wieku katedra kamieniecka została przebudowana w stylu barokowym. W 1866 r. diecezja kamieniecka została zniesiona, a katedra spadła do rangi kościoła parafialnego. W latach 1919-1920 na krótko przywrócono jej status, jednak gdy do Kamieńca wkroczyli bolszewicy, w latach 30. umieścili w budynku katedry muzeum ateizmu ${ }^{35}$. W okresie okupacji niemieckiej dzięki staraniom wiernym udało się odzyskać kościół. W 1945 r. pełnomocnik zarejestrował wspólnotę katolicką przy kościele pokatedralnym. Jednakże już w lipcu 1946 r. wspólnocie odebrano rejestrację, a kościół ponownie przekształcono na muzeum ateizmu ${ }^{36}$.

Podczas wojny niemiecko-radzieckiej część miejscowych katolików uczestniczyła w nabożeństwach w kaplicy przy byłym kościele ormiańskokatolickim. W styczniu 1945 r. pełnomocnik Rady ds. kultów religijnych zarejestrował tam wspólnotę. W 1948 r. decyzją władz obwodowych kaplicę zamknięto, a wspólnotę rozwiązano ${ }^{37}$.

\section{Kitajgród}

Drewniany kościół w Kitajgrodzie wybudowano w 1721 r. Po kilkudziesięciu latach zastąpiono go świątynią murowaną, odrestaurowaną w $1913 \mathrm{r}^{38} \mathrm{~W}$ latach 1937-1941 świątynia była wykorzystywana przez kołchoz. W okresie okupacji

35 J. Kopczyński, Kamieniec Podolski, w: Miasta wielu religii. Topografia sakralna ziem wschodnich dawnej Rzeczypospolitej, red. M. Jakubowski, M. Sas, F. Walczyna, Warszawa 2016, s. 74-91; A. Prusiewicz, Kamieniec Podolski. Szkic historyczny, Kijów-Warszawa 1915, s. 123; Z. Bania, M. Wiraszka, Kamieniec Podolski. Miasto - legenda. Zarys dziejów urbanistyki i architektury od czasów najdawniejszych do współczesności, Warszawa 2001, s. 95-99; K. Iwanicki, Katedra w Kamieńcu, Warszawa 1930; R. Król-Mazur, Miasto trzech nacji. Studia z dziejów Kamieńca Podolskiego w XVIII wieku, Kraków 2008, s. 345-346; D. Kołodziejczyk, Podole pod panowaniem tureckim. Ejalet kamieniecki 1672-1699, Warszawa 1994, s. 188-189; Pasiecznik, Rimo-katoliczieskije obszcziny, s. 94-95; Kamieniec Podolski, w: Stownik geograficzny, t. 3, Warszawa 1882, s. 759.

${ }^{36}$ APOCh, Ispołnitielnyj komitiet Kamieniec-Podolskogo obłastnogo Sowieta dieputatow trudiaszczichsia, fund. P-338, op. 15, spr. 1919, Sprawka o riegistracyi rieligioznogo obszcziestwa, 18 IV 1945, k. 132; APOCh, Ispołnitielnyj komitiet Kamieniec-Podolskogo obłastnogo Sowieta dieputatow trudiaszczichsia, fund. P-338, op. 15, spr. 1919, Rieszenije Ispołnitielnogo Komitieta Kamieniec-Podolskogo Obłastnogo Sowieta dieputatow trudiaszczichsia, 2 VIII 1946, k. 130; APOCh, Ispołnitielnyj komitiet Kamieniec-Podolskogo obłastnogo Sowieta dieputatow trudiaszczichsia, fund. P-338, op. 15, spr. 1919, Akt, 4 IV 1945, k. 108; APOCh, Ispołnitielnyj komitiet Kamieniec-Podolskogo obłastnogo Sowieta dieputatow trudiaszczichsia, fund. P-338, op. 15, spr. 1919, Zakluczienie, 2 VIII 1946, k. 129.

${ }^{37}$ Pasiecznik, Rimo-katoliczieskije obszcziny, s. 96

${ }^{38}$ Tamże, s. 97; Kitajgód, w: Słownik geograficzny, t. 4, Warszawa 1883, s. 115. 
niemieckiej kościół powrócił do kultu religijnego. W 1945 r. pełnomocnik Rady ds. kultów religijnych w obwodzie kamieniecko-podolskim zarejestrował wspólnotę katolicką w Kitajgrodzie ${ }^{39}$. Wspominany kościół funkcjonował przez cały okres władzy sowieckiej.

\section{Kołybań}

W 1929 r. kaplica w Kołybaniu, wybudowana w XVII wieku, została przekształcona przez Sowietów na fermę drobiu. W okresie wojny niemiecko-radzieckiej miejscowi katolicy usiłowali odnowić świątynię ${ }^{40}$. W maju 1945 r. wspólnota katolicka została oficjalnie zarejestrowana przez pełnomocnika Rady ds. kultów religijnych ${ }^{41}$. Decyzją Obwodowego Komitetu Wykonawczego z 1950 r. kaplica została przekazana na potrzeby kołchozu, a wspólnota rozwiązana ${ }^{42}$.

\section{Krasilów}

Kościół w Krasiłowie (filia parafii Kulczyny) powstał w $1860 \mathrm{r}^{43} \mathrm{~W}$ okresie międzywojennym pełnił on funkcje domu kultury i kina, a następnie magazynu gospodarczego. Podczas okupacji niemieckiej kościół znalazł się w dyspozycji miejscowych katolików. W kwietniu 1945 r. wspólnota w Krasiłowie została oficjalnie zarejestrowana przez władze sowieckie ${ }^{44}$. W lutym 1949 r. władze obwodowe przeznaczyły świątynię na potrzeby gospodarcze. W 1951 r. wspólnota katolicka została rozwiązana. Po dziesięciu latach w budynku pokościelnym urządzono dom pionierów ${ }^{45}$.

\section{Kupin}

Kościół w Kupinie został ufundowany w 1714 r. Od 1745 do 1832 r. opiekę duszpasterską sprawowali tam karmelici bosi. Po powstaniu listopadowym władze carskie przekazały kościół w Kupinie Cerkwii prawosławnej ${ }^{46}$. W latach 30.

${ }^{39}$ APOCh, Ispołnitielnyj komitiet Kamieniec-Podolskogo obłastnogo Sowieta dieputatow trudiaszczichsia, fund. P-338, op. 9, spr. 14, Spiec'zapiska o naliczii rimsko-katoliczieskich obszczin i namiecziajemyje mieroprijatija po otsieleniju molitwiennych domow /kostiołow, kaplic/, rospusku i sniatiju s riegistracyi obszczin etogo kulta, 28 VIII 1949, k. 76.

${ }^{40}$ Kotybanie, w: Stownik geograficzny, t. 4, Warszawa 1883, s. 296; O. Pasiecznik, Rimo-katoliczieskije obszcziny, s. 96.

${ }^{41}$ APOCh, Ispołnitielnyj komitiet Kamieniec-Podolskogo obłastnogo Sowieta dieputatow trudiaszczichsia, fund. P-338, op. 9, spr. 10, Dokładnaja zapiska o sostojanii i diejatielnosti rimskokatoliczieskoj cerkwi po Kamieniec-Podolskoj obłasti na 15 awgusta 1948 g., 15 VIII 1948, k. 127.

${ }^{42}$ Pasiecznik, Rimo-katoliczieskije obszcziny, s. 98.

${ }^{43}$ Krasilow, w: Stownik geograficzny, t. 4, Warszawa 1883, s. 615.

${ }^{44}$ APOCh, Ispołnitielnyj komitiet Kamieniec-Podolskogo obłastnogo Sowieta dieputatow trudiaszczichsia, fund. P-338, op. 9, spr. 14, Spiec'zapiska o naliczii rimsko-katoliczieskich obszczin i namiecziajemyje mieroprijatija po otsieleniju molitwiennych domow /kostiołow, kaplic/, rospusku i sniatiju s riegistracyi obszczin etogo kulta, 28 VIII 1949, k. 72.

${ }^{45}$ Pasiecznik, Rimo-katoliczieskije obszcziny, s. 96-97.

${ }^{46}$ Kupin, w: Stownik geograficzny, t. 4, Warszawa 1883, s. 886; Pasiecznik, Rimo-katoliczieskije obszcziny, s. 97. 
XX wieku świątynia została zdewastowana przez Sowietów. W 1945 r. władze wyraziły zgodę na rejestrację wspólnoty katolickiej w Kupinie. Miejscowi wierni spotykali się na nabożeństwach w domu prywatnym. W 1950 r. władze sowieckie zamknęły kaplicę i rozwiązały wspólnotę katolicką w Kupinie ${ }^{47}$.

\section{Kumanów}

Drewniany kościół w Kumanowie został ufundowany w XVII wieku. Po kilkudziesięciu latach został zniszczony przez Turków. W 1717 r. wybudowano nową świątynię. W 1932 r. decyzją władz sowieckich przekształcono ją na klub. W okresie okupacji niemieckiej kościół został przekazany miejscowym katoli$\mathrm{kom}^{48}$. Po wkroczeniu wojsk sowieckich kościół pełnił funkcję spichlerza. Po pewnym czasie Rada ds. kultów religijnych zarejestrowała wspólnotę katolicką w Kumanowie i w kościele zaczęto ponownie odprawiać nabożeństwa ${ }^{49}$. W $1951 \mathrm{r}$. wspólnota została wyrejestrowana, a świątynia przeznaczona na cele kulturalno-oświatowe. W 1956 r. kościół w Kumanowie pełnił funkcję magazynu. Budynek świątyni był zaniedbany i wymagał remontu ${ }^{50}$.

\section{Latyczów}

Pierwsza parafia rzymskokatolicka w Latyczowie została erygowana ok. 1430 r. Podczas najazdu Tatarów w 1453 r. latyczowski kościół wraz z całym miastem został spalony. W $1546 \mathrm{r}$. wybudowano nową świątynię ${ }^{51}$. Na prośbę bpa kamienieckiego Pawła Wołuckiego w 1590 r. papież Klemens VIII wysłał do Latyczowa Dominikanów, w celu ewangelizacji tamtejszej ludności, nękanej przez częste najazdy tatarskie ${ }^{52}$. Od 1832 r. opiekę duszpasterską w latyczowskim ko-

${ }^{47}$ APOCh, Ispołnitielnyj komitiet Kamieniec-Podolskogo obłastnogo Sowieta dieputatow trudiaszczichsia, fund. P-338, op. 15, spr. 1907, Sprawka o riegistracyi rieligioznogo obszcziestwa, 25 IV 1945, k. 73; APOCh, Ispołnitielnyj komitiet Kamieniec-Podolskogo obłastnogo Sowieta dieputatow trudiaszczichsia, fund. P-338, op. 15, spr. 1907, Upołnomocziennomu Sowieta po diełam rieligioznych kultow pri Sowietie Ministrow SSSR po Kamieniec-Podolskoj obłasti, 25 IV 1950, k. 76; APOCh, Ispołnitielnyj komitiet Kamieniec-Podolskogo obłastnogo Sowieta dieputatow trudiaszczichsia, fund. P-338, op. 15, spr. 1907, Upołnomocziennomu Sowieta po diełam rieligioznych kultow pri Sowietie Ministrow SSSR po Kamieniec-Podolskoj obłasti, 17 VIII 1950, k. 82-83; APOCh, Ispołnitielnyj komitiet Kamieniec-Podolskogo obłastnogo Sowieta dieputatow trudiaszczichsia, fund. P-338, op. 15, spr. 1907, Rieszenije nr 1418 Ispołnitielnogo komitieta kamieniec-Podolskogo obłastnogo Sowieta dieputatow trudiaszczichsia, 21 VIII 1950, k. 87; APOCh, Ispołnitielnyj komitiet Kamieniec-Podolskogo obłastnogo Sowieta dieputatow trudiaszczichsia, fund. P-338, op. 15, spr. 1907, Zakluczienije, 17 VIII 1950, k. 85-86.

${ }^{48}$ Pasiecznik, Rimo-katoliczieskije obszcziny, s. 98.

${ }^{49} \mathrm{APOCh}$, Ispołnitielnyj komitiet Kamieniec-Podolskogo obłastnogo Sowieta dieputatow trudiaszczichsia, fund. P-338, op. 9, spr. 14, Informacyonnyj otcziot o rabotie Upołnomocziennogo Sowieta po diełam rieligioznych kultow pri Sowietie Ministrow SSSR, pri Kamieniec-Podolskom obł'ispołkomie za III kw. 1949 g., 22 X 1949, k. 103.

${ }^{50}$ Pasiecznik, Rimo-katoliczieskije obszcziny, s. 98-99.

${ }^{51}$ Latyczów, w: Stownik geograficzny, t. 5, Warszawa 1884, s. 99-100.

${ }^{52}$ A. Wolińska-Wójtowicz, Matka Boża Latyczowska, Lublin 2014, s. 11. 
ściele zaczęli sprawować księża diecezjalni ${ }^{53}$. W 1933 r. cały kompleks zabudowań podominikańskich został zajęty przez władze sowieckie. W świątyni urządzono stajnię dla koni. W latach 1939-1941 kościół wraz z klasztorem pełnił funkcję więzienia ${ }^{54}$. Podczas okupacji niemieckiej w kościele latyczowskim mieścił się obóz jeniecki. Miejscowi katolicy gromadzili się na nabożeństwa w kaplicy cmentarnej, wybudowanej w 1900 r. i odebranej przez Sowietów w 1936 r. ${ }^{55}$ W 1948 r. władze sowieckie zarejestrowały wspólnotę katolicką w Latyczowie ${ }^{56}$. Po pewnym czasie w kaplicy cmentarnej przeprowadzono remont ${ }^{57}$. Natomiast kościół i zabudowania podominikańskie po zakończeniu wojny zostały przekształcone na magazyny nawozów, paliwa i materiałów budowlanych ${ }^{58}$. Latyczowska wspólnota katolicka legalnie funkcjonowała przez cały okres sowiecki. W latach 1956-1959 proboszczem w Latyczowie był ks. Faustyn Lisicki.

\section{Manikowce}

Na początku XX wieku w Manikowcach, na miejscu zniszczonej kaplicy cmentarnej, wybudowano nową świątynię. W 1935 r. decyzją władz sowieckich przekształcono ją na magazyn gospodarczy. Podczas okupacji niemieckiej świątynia ponownie znalazła się w dyspozycji miejscowych katolików. W kwietniu 1945 r. manikowiecka wspólnota katolicka została oficjalnie zarejestrowana przez obwodowego pełnomocnika Rady ds. kultów religijnych ${ }^{59}$. Kaplica w Manikowcach otwarta była przez cały okres władzy sowieckiej. W latach 1959-1991 parafię manikowiecką obsługiwał duszpastersko ks. Jan Olszański, późniejszy biskup diecezji kamieniecko-podolskiej.

\section{Mińkowce}

Kościół pw. Podwyższenia Krzyża Świętego został ufundowany w 1797 r. $^{60}$. W 1935 r. władze sowieckie zdecydowały o zamknięciu świątyni i rozebraniu ją

${ }^{53}$ H.I. Szumił, „Nigdym ja ciebie, ludu, nie rzuciła”. Z dziejów latyczowskiej Ikony, LublinSandomierz 2015, s. 105.

${ }^{54}$ L. Nowicka, Istorycznymy steżkamy ridnogo mista, Łetycziw 2012, s. 26-27.

${ }^{55}$ Pasiecznik, Rimo-katoliczieskije obszcziny, s. 99.

${ }^{56}$ APOCh, Sowiet po diełam rieligii pri Sowietie Ministrow Ukrainy. Upołnomocziennyj Sowieta po diełam religii pri Kabinietie Ministrow Ukrainy, fund. P-6416, op. 1, spr. 45, Sprawka o riegistracyi rieligioznogo obszcziestwa, 2 X 1948, k. 178; APOCh, Ispołnitielnyj komitiet Kamieniec -Podolskogo obłastnogo Sowieta dieputatow trudiaszczichsia, fund. P-338, op. 9, spr. 14, Informacyonnyj otcziot o rabotie Upołnomocziennogo Sowieta po diełam rieligioznych kultow pri Sowietie Ministrow SSSR po Kamieniec-Podolskoj obłiasti za IV kw. 1949 goda, 13 II 1950, k. 133

${ }^{57}$ Pasiecznik, Rimo-katoliczieskije obszcziny, s. 99.

${ }^{58}$ H.I. Szumił, Sanktuarium Matki Bożej Latyczowskiej, Sandomierz 1994, s. 27.

${ }^{59}$ APOCh, Ispołnitielnyj komitiet Kamieniec-Podolskogo obłastnogo Sowieta dieputatow trudiaszczichsia, fund. P-338, op. 9, spr. 14, Informacyonnyj otcziot o rabotie Upołnomocziennogo Sowieta po diełam rieligioznych kultow pri Sowietie Ministrow SSSR, pri Kamieniec-Podolskom obł'ispołkomie za III kw. 1949 g., 22 X 1949, k. 107.

${ }^{60}$ Mińkowce, w: Słownik geograficzny, t. 6, Warszawa 1885, s. 448. 
na materiały budowlane. Zamknęły również kaplicę cmentarną. W 1945 r. miejscowi katolicy własnym kosztem odremontowali kaplicę na cmentarzu. W tym samym roku władze obwodowe zarejestrowały wspólnotę katolicką w Mińkow$\mathrm{cach}^{61}$. Wspólnota ta funkcjonowała legalnie aż do upadku ZSRR.

\section{Ploskirów (Ploskirow, Chmielnicki)}

Kościół pw. św. Anny w Płoskirowie wybudowano w XVII wieku. W latach 1710-1714 r. ufundowano nowy drewniany kościół. W 1801 r. rozpoczęto zbiórkę ofiar na budowę murowanego kościoła, który został ukończony w 1820 r. Na początku XX w. świątynię przebudowano w stylu barokowym stylu ${ }^{62}$. Po włączeniu Podola do państwa sowieckiego kościół został zdewastowany, a dom parafialny przeznaczony na potrzeby archiwum miejskiego. Po wkroczeniu do Płoskirowa wojsk niemieckich pomieszczenie domu parafialnego znalazło się w dyspozycji wiernych. W 1945 r. wspólnota katolicka w Płoskirowie została oficjalnie zarejestrowana przez obwodowego pełnomocnika Rady ds. kultów religijnych. W 1950 r. władze obwodowe pod pretekstem braku duszpasterza i małej liczby wiernych podjęły decyzję o rozwiązaniu wspólnoty katolickiej, a kaplicę przekazały na potrzeby miejscowego archiwum ${ }^{63}$.

\section{Polonne}

Początkowo w Połonnem funkcjonowały dwa kościoły: pw. św. Antoniego i pw. św. Anny. Po ich spaleniu, w 1607 r. wojewoda krakowski Stanisław Lubomirski ufundował nowy kościół pw. św. Anny. W 1618 r. miasto wraz z kościołem zostało ponownie spalone przez Tatarów. W $1646 \mathrm{r}$. świątynię odbudowano, jednak po kilku latach została ona zniszczona przez wojska Bohdana Chmielnickiego. W 1716 r. kościół został ponownie wyremontowany ${ }^{64}$. W latach 30 . XX wieku świątynia została zamknięta przez Sowietów i przeznaczona na stajnię. W $1937 \mathrm{r}$. władze państwowe próbowały ją rozebrać, jednakże natknęły się na silny opór wiernych ${ }^{65}$. Z czasem w kościele urządzono więzienie NKWD. W podziemiach

${ }^{61}$ APOCh, Ispołnitielnyj komitiet Kamieniec-Podolskogo obłastnogo Sowieta dieputatow trudiaszczichsia, fund. P-338, op. 9, spr. 14, Informacyonnyj otcziot o rabotie Upołnomocziennogo Sowieta po diełam rieligioznych kultow pri Sowietie Ministrow SSSR, pri Kamieniec-Podolskom obł'ispołkomie za III kw. 1949 g., 22 X 1949, k. 107.

${ }^{62}$ O. Pasiecznik, Parafija i chram u Proskurowi do 1917 roku, „Studia Catholica Podoliae”, nr 6 (2012), s. 321-345.

${ }^{63}$ APOCh, Ispołnitielnyj komitiet Kamieniec-Podolskogo obłastnogo Sowieta dieputatow trudiaszczichsia, fund. P-338, op. 9, spr. 14, Spiec'zapiska o naliczii rimsko-katoliczieskich obszczin i namiecziajemyje mieroprijatija po otsieleniju molitwiennych domow /kostiołow, kaplic/, rospusku i sniatiju s riegistracyi obszczin etogo kulta, 28 VIII 1949, k. 86; APOCh, Ispołnitielnyj komitiet Kamieniec-Podolskogo obłastnogo Sowieta dieputatow trudiaszczichsia, fund. P-338, op. 15, spr. 1907, Zakluczienie, 17 VIII 1950, k. 85-86.

${ }^{64}$ Polonne, w: Stownik geograficzny..., t. 8, Warszawa 1887, s. 727-728.

${ }^{65}$ Pasiecznik, Rimo-katoliczieskije obszcziny, s. 100-101. 
świątyni regularnie dokonywano tortur i egzekucji ${ }^{66}$. W okresie okupacji niemieckiej kościółponowniezostał otwarty dla wiernych.Podczas wycofywania się zwojsk niemieckich z Połonnego w budynek kościelny trafiła bomba lotnicza. $Z$ tego też powodu miejscowi katolicy musieli podjąć się remontu świątyni ${ }^{67}$. W czerwcu 1945 r. wspólnota parafialna w Połonnem otrzymała rejestrację ${ }^{68}$. Władze państwowe niejednokrotnie podejmowały próby rozwiązania wspólnoty. W okresie sowieckim posługę duszpasterską przy parafii pw. św. Anny w Połonnem pełnili kolejno: ks. Antoni Chomicki, ks. Andrzej Gładysiewicz i o. Stanisław Szyrokoradiuk $\mathrm{OFM}^{69}$.

\section{Satanów}

Kościół pw. św. Trójcy został wzniesiony w 1581 r. Nową świątynię ufundowano w $1646 \mathrm{r}$. W latach 30. XX wieku władze sowieckie wysadziły kościół w powietrze ${ }^{70}$. W okresie okupacji niemieckiej miejscowi katolicy usiłowali odbudować kapliczkę przy zniszczonym kościele. Po powrocie władzy sowieckiej wierni zwracali się do władz państwowych z prośbą o przekazanie kaplicy, jednak bezskutecznie. Kaplicę przekształcono na szkołę ${ }^{71}$.

\section{Skazińce}

Kościół w Skazińcach wzniesiono w 1766 r. Po kilkudziesięciu latach wybudowano świątynię murowaną ${ }^{72}$. Od 1936 r. władze roku sowieckie wykorzystywały świątynię jako dom kultury. Podczas okupacji niemieckiej miejscowi katolicy usiłowali odzyskać kościół. W maju 1945 r. władze obwodowe zarejestrowały wspólnotę katolicką w Skazińcach, jednak w 1950 r. została ona wykreślona z rejestru. Kościół przejęły władze państwowe i urządziły w nim dom kultury ${ }^{73}$.

${ }^{66}$ R. Dzwonkowski, Losy duchowieństwa katolickiego w ZSSR 1917-1939. Martyrologium, Lublin 1998, s. 255.

${ }^{67}$ Pasiecznik, Rimo-katoliczieskije obszcziny, s. 101.

${ }^{68} \mathrm{APOCh}$, Ispołnitielnyj komitiet Kamieniec-Podolskogo obłastnogo Sowieta dieputatow trudiaszczichsia, fund. P-338, op. 9, spr. 14, Informacyonnyj otcziot o rabotie Upołnomocziennogo Sowieta po diełam rieligioznych kultow pri Sowietie Ministrow SSSR, pri Kamieniec-Podolskom obł'ispołkomie za III kw. 1949 g., 22 X 1949, k. 101.

${ }^{69}$ APOCh, Sowiet po diełam rieligii pri Sowietie Ministrow Ukrainy. Upołnomocziennyj Sowieta po diełam religii pri Kabinietie Ministrow Ukrainy, fund. P-6416, op. 1, spr. 45, Zakluczienije upołnomocziennogo Sowieta po dielam rieligioznych kultow pri ispołkomie Chmielnickogo obłastnogo Sowieta dieputatow trudiaszczichsia na sniatije s riegistracyi rimsko-katoliczieskogo rieligioznogo obszcziestwa w g. Połonnom, Połonskogo rajona, 21 VII 1961, k. 285-287; APOCh, Sowiet po diełam rieligii pri Sowietie Ministrow Ukrainy. Upołnomocziennyj Sowieta po diełam religii pri Kabinietie Ministrow Ukrainy, fund. P-6416, op. 1, spr. 45, Sprawka, 15 III 189, k. 316.

${ }^{70}$ Antkiewicz, Satanów, w: Miasta wielu religii, s. 125-128.

${ }^{71}$ Pasiecznik, Rimo-katoliczieskije obszcziny, s. 102.

${ }^{72}$ Tamże, s. 111; Skazińce w: Stownik geograficzny, t. 10, Warszawa 1889, s. 664

${ }^{73}$ APOCh, Ispołnitielnyj komitiet Kamieniec-Podolskogo obłastnogo Sowieta dieputatow trudiaszczichsia, fund. P-338, op. 9, spr. 14, Spiec'zapiska o naliczii rimsko-katoliczieskich obszczin i namiecziajemyje mieroprijatija po otsieleniju molitwiennych domow /kostiołow, kaplic/, rospusku i sniatiju s riegistracyi obszczin etogo kulta, 28 VIII 1949, k. 87; APOCh, Ispołnitielnyj komitiet 


\section{Slawuta}

Budowę kościoła w Sławucie zrealizowano w latach 1822-1845. W 1932 r. świątynia została zamknięta i przekształcona na magazyn wojskowy. Podczas wojny niemiecko-sowieckiej wierni odzyskali kościół. W 1945 pełnomocnik Rady ds. kultów religijnych zarejestrował wspólnotę katolicką w Sławucie. W 1950 r. władze obwodowe zdecydowały o zamknięciu świątyni i urządzenia w niej domu kultury. W tym samym roku wspólnota została wykreślona z rejestru. Z czasem wierni zaczęli gromadzić się na nabożeństwa w kaplicy cmentarnej ${ }^{74}$.

\section{Solobkowce}

Kościół pw. św. Józefa w Sołobkowcach został ufundowany w 1650 r. Kilkakrotnie podlegał restauracji ${ }^{75}$. W latach 20 . XX wieku władze sowieckie upaństwowiły dom parafialny i przeznaczyły go na potrzeby oddziału komunalnego, a następnie komisariatu wojskowego. W latach 1936-1937 kościół uległ dewastacji. W okresie okupacji niemieckiej wierni odzyskali dom parafialny i wykorzystywali go do nabożeństw. Po zakończeniu wojny władze sowieckie odmówiły rejestracji wspólnoty w Sołobkowcach, jednak wierni nadal spotykali się na nabożeństwach w domu parafialnym. W 1949 r. władze państwowe przyjęły wspomniany budynek i doprowadziły do jego dewastacji ${ }^{76}$.

Kamieniec-Podolskogo obłastnogo Sowieta dieputatow trudiaszczichsia, fund. P-338, op. 15, spr. 1907, Gołowi Wykonawczogo komitetu Kamjanec-Podilskoji obasti Rady deputatiw trudiaszczych, 19 IX 1949, k. 119-120; APOCh, Ispołnitielnyj komitiet Kamieniec-Podolskogo obłastnogo Sowieta dieputatow trudiaszczichsia, fund. P-338, op. 15, spr. 1907, Zakluczienie, 25 II 1950, k. 124; APOCh, Ispołnitielnyj komitiet Kamieniec-Podolskogo obłastnogo Sowieta dieputatow trudiaszczichsia, fund. P-338, op. 15, spr. 1907, Rieszenije Istokoma Jarmolinieckogo Rajsowieta dieputatow trudiaszczichsia Kamieniec-Podolskoj obasti o zakrytii kostioła w siele Skazincy i pieriedaczie ego pod sielskij dom kultury i bibliotieku, 6 III 1950, k. 122.

${ }^{74}$ Pasiecznik, Rimo-katoliczieskije obszcziny, s. 102.

${ }^{75}$ Solodkowce, w: Stownik geograficzny, t. 11, Warszawa 1890, s. 58-59.

${ }^{76}$ APOCh, Ispołnitielnyj komitiet Kamieniec-Podolskogo obłastnogo Sowieta dieputatow trudiaszczichsia, fund. P-338, op. 15, spr. 1907, Akt, 17 V 1946, k. 304; APOCh, Ispołnitielnyj komitiet Kamieniec-Podolskogo obłastnogo Sowieta dieputatow trudiaszczichsia, fund. P-338, op. 15, spr. 1907, Priedsiedatielu Kamieniec-Podolskogo Obastnogo Sowieta dieputatow trudiaszczichsia Towariszczu Kowbasiuku, 8 VI 1946, k. 307; APOCh, Ispołnitielnyj komitiet Kamieniec-Podolskogo obłastnogo Sowieta dieputatow trudiaszczichsia, fund. P-338, op. 15, spr. 1907, Akt, 31 V 1948, k. 310; APOCh, Ispołnitielnyj komitiet Kamieniec-Podolskogo obłastnogo Sowieta dieputatow trudiaszczichsia, fund. P-338, op. 15, spr. 1907, Rieszenije nr 51 zasiedanija ispołnitielnogo komitieta Sołobkowieckogo Rajonnogo Sowieta dieputatow trudiaszczichsia Kamieniec-Podolskoj obasti, 17 VI 1948, k. 309; APOCh, Ispołnitielnyj komitiet Kamieniec-Podolskogo obłastnogo Sowieta dieputatow trudiaszczichsia, fund. P-338, op. 15, spr. 1907, Rieszenije nr 1241 Ispołnitielnogo Komitieta Kamieniec-Podolskogo obastnogo Sowieta dieputatow trudiaszczichsia o zakrytii molitwiennogo doma i rospuskie rimsko-katoliczieskoj obszcziny w s. Sołobkowcy, Sołobkowieckogo rajona, 5 VIII 1949, k. 311. 


\section{Starokonstantynów}

Budowę kościoła pw. św. Jana Chrzciciela rozpoczęto w 1752 r. Świątynię poświęcono w 1778 r. ${ }^{77}$ Władze sowieckie w 1934 r. przekształciły kościół na klub. W okresie okupacji niemieckiej budynek odzyskali miejscowi katolicy. W $1945 \mathrm{r}$. wspólnota parafialna w Starokonstantynowie została zarejestrowana ${ }^{78}$. Jednak w 1949 r. została rozwiązana, a kościół przeznaczono na klub ${ }^{79}$.

\section{Struga}

Kościół pw. Wszystkich Świętych w Strudze został ufundowany w 1814 r. ${ }^{80}$ W 1930 r. został zamknięty i przekształcony na magazyn zboża. W okresie okupacji niemieckiej świątynia została przekazany miejscowym katolikom. W $1945 \mathrm{r}$. władze sowieckie zarejestrowały wspólnotę katolicką w Strudze ${ }^{81}$, która legalnie funkcjonowała przez cały okres sowiecki.

\section{Szarowka}

Pierwsza drewniana świątynia katolicka w Szarowce została ufundowana w XV wieku. W 1607 r. wzniesiono kościół, w którym do 1832 r. posługę duszpasterską pełnili dominikanie. W 1832 r. świątynia została przekazana Cerkwii prawosławnej. W 1861 r. w Szarowce wybudowano nowy kościół pw. Matki Bożej Różańcowej $^{82}$. W połowie lat 30 . XX wieku świątynię przejęły władze państwowe z przeznaczeniem na klub i bibliotekę. W okresie wojny niemiecko-sowieckiej w kościele zaczęto ponownie odprawiać nabożeństwa. W 1945 r. obwodowy pełnomocnik na wniosek wiernych zarejestrował wspólnotę katolicką ${ }^{83}$ W $1950 \mathrm{r}$.

77 Starokonstantynów, w: Stownik geograficzny, t. 11, Warszawa 1890, s. 257-259.

${ }^{78}$ APOCh, Ispołnitielnyj komitiet Kamieniec-Podolskogo obłastnogo Sowieta dieputatow trudiaszczichsia, fund. P-338, op. 9, spr. 14, Spiec'zapiska o naliczii rimsko-katoliczieskich obszczin i namiecziajemyje mieroprijatija po otsieleniju molitwiennych domow /kostiołow, kaplic/, rospusku i sniatiju s riegistracyi obszczin etogo kulta, 28 VIII 1949, k. 89.

${ }^{79} \mathrm{APOCh}$, Ispołnitielnyj komitiet Kamieniec-Podolskogo obłastnogo Sowieta dieputatow trudiaszczichsia, fund. P-338, op. 15, spr. 1907, Rieszenije nr 775 Ispołnitielnogo Komitieta Kamieniec-Podolskogo Obłastnogo Sowieta dieputatow trudiaszczichsia o sniatii s riegistracyi i rospuskie rieligioznoj obszcziny rimsko-katoliczieskoj cerkwi w gor. Starokonstantinowo, 19 V 1950, k. 263; APOCh, Ispołnitielnyj komitiet Kamieniec-Podolskogo obłastnogo Sowieta dieputatow trudiaszczichsia, fund. P-338, op. 15, spr. 1907, Upołnomoczenomu Sowieta po diełam rieligoznych kultow pri Chmielnickom obł'ispołkomie, 23 VIII 1954, k. 269.

${ }^{80}$ Struga, w: Stownik geograficzny, t. 11, Warszawa 1890, s. 415.

${ }^{81}$ APOCh, Ispołnitielnyj komitiet Kamieniec-Podolskogo obłastnogo Sowieta dieputatow trudiaszczichsia, fund. P-338, op. 9, spr. 14, Informacyonnyj otcziot o rabotie Upołnomocziennogo Sowieta po diełam rieligioznych kultow pri Sowietie Ministrow SSSR, pri Kamieniec-Podolskom obł'ispołkomie za III kw. 1949 g., 22 X 1949, k. 104.

${ }^{82}$ Szarowka, w: Stownik geograficzny, t. 11, Warszawa 1890, s. 792-793; Pasiecznik, Rimo-katoliczieskije obszcziny, s. 110.

${ }^{83} \mathrm{APOCh}$, Ispołnitielnyj komitiet Kamieniec-Podolskogo obłastnogo Sowieta dieputatow trudiaszczichsia, fund. P-338, op. 9, spr. 14, Spiec'zapiska o naliczii rimsko-katoliczieskich obszczin 
władze obwodowe podjęły jednak decyzję o przekształceniu świątyni na klub oraz rozwiązaniu wspólnoty ${ }^{84}$.

\section{Tarnoruda}

Siedemnastowieczny kościół w Tarnorudzie, słynący z cudownego obrazu Chrystusa Ubiczowanego, zwanego Chrystusem Tarnorudzkim, został zamknięty przez Sowietów w 1934 r. Świątynię przekształcono na klub, a następnie na elektrownię ${ }^{85}$. W 1942 r. miejscowi katolicy przeprowadzili remont kościoła. W czerwcu 1945 r. tarnorudzka wspólnota katolicka podpisała umowę z Komitetem Wykonawczym rejonu wołoczyskiego o wynajęciu budynku kościelnego ${ }^{86}$. W $1951 \mathrm{r}$. władze obwodowe przyjęły decyzję o zamknięciu świątyni ${ }^{87}$. Budynek kościelny wykorzystywano jako magazyn narzędzi rolniczych, a od lat 60. przechowywano w nim nawozy mineralne ${ }^{88}$.

\section{Tynna}

Pierwsza drewniana świątynia katolicka w Tynnej uległa zniszczeniu pod koniec XVI w. W 1596 r. wzniesiono kościół murowany pw. św. Katarzyny Aleksandryjskiej. W XVIII w. zbudowano nowy kościół pw. Wniebowzięcia Najświętszej Maryi Panny i św. Wojciecha ${ }^{89}$. W latach 30 . XX wieku świątynia została zamknięta i wykorzystywana jako magazyn. W 1945 r. wspólnota katolicka w Tynnej została oficjalnie zarejestrowana przez pełnomocnika Rady ds. kultów religijnych. W 1950 r. władze obwodowe skreśliły wspólnotę z rejestru. Kościół, który znajdował się w bardzo złym stanie technicznym, został zamknięty i przekazany na potrzeby kołchozu. Budynek świątyni rozbierano na cegły, i po kościele pozostały tylko części ścian ${ }^{90}$.

i namiecziajemyje mieroprijatija po otsieleniju molitwiennych domow /kostiołow, kaplic/, rospusku i sniatiju s riegistracyi obszczin etogo kulta, 28 VIII 1949, k. 82.

${ }^{84} \mathrm{APOCh}$, Ispołnitielnyj komitiet Kamieniec-Podolskogo obłastnogo Sowieta dieputatow trudiaszczichsia, fund. P-338, op. 15, spr. 1907, Zakluczienie, 2 VII 1954, k. 201-202.

${ }^{85}$ Tarnoruda, w: Stownik geograficzny, t. 10, Warszawa 1889, s. 195.

${ }^{86}$ APOCh, Ispołnitielnyj komitiet Kamieniec-Podolskogo obłastnogo Sowieta dieputatow trudiaszczichsia, fund. P-338, op. 15, spr. 1907, Rieszenije nr 337 Ispołnitielnogo Komitieta Kamieniec-Podolskogo obłastnogo Sowieta dieputatow trudiaszczichsia o pieriedaczie pomieszczienija pod sielskij dom kultury i bibliotieku, sniatii s riegistracyi i rospuskie rimsko-katoliczieskoj obszcziny rimsko-katoliczieskoj cerwi w s. Szarowka, Jarmolinieckogo rajona, 1 III 1950, k. 181.

${ }^{87} \mathrm{APOCh}$, Ispołnitielnyj komitiet Chmielnickogo obłastnogo Sowieta dieputatow trudiaszczichsia, fund. P-338, op. 15, spr. 1909, Zakluczienie, 30 III 1951, k. 53-54.

${ }^{88} \mathrm{APOCh}$, Sowiet po diełam rieligii pri Sowietie Ministrow Ukrainy. Uponomocziennyj Sowieta po diełam rieligii pri Kabinietie Ministrow Ukrainy po Chmielnickoj, fund. P-6416, op. 1, spr. 43, Zakluczienie o riegistracyi objedinienija rimsko-katoliczieskoj cerwi w s. Tarnoruda, 3 X 1988, k. 80; Rożkow, Ksiądz Władystaw Wanags, s. 65.

${ }^{89}$ W. Słobodian, Korotkyj istorycznyj oglad kultu Materi Bożoji Tyniańskoji, „Studia Catholica Podoliae", (2014-2015) nr 8-9, s. 321-326.

${ }^{90}$ Pasiecznik, Rimo-katoliczieskije obszcziny, s. 105. 


\section{Wińkowce}

Kościół pw. Matki Bożej Anielskiej wybudowano w 1643 r. W 1780 r. wzniesiono nowy kościół. Do 1832 r. parafię obsługiwali Franciszkanie konwentualni. Na początku XX wieku świątynię odrestaurowano ${ }^{91}$. W 1934 r. władze sowieckie zamknęły kościół, a w 1936 r. przeznaczyły go na cele kulturalno-oświatowe (biblioteki i domu kultury). W okresie okupacji niemieckiej wiernym udało się odzyskać kościół. W czerwcu 1945 r. władze sowieckie zarejestrowały wspólnotę katolicką w Wińcowcach ${ }^{92}$. Jednak decyzją Obwodowego Komitetu Wykonawczego z 1949 r. budynek kościoła w Wińkowcach miał być przebudowany na bibliotekę. Ostatecznie świątynia została zamknięta w 1950 r. pod pretekstem konieczności wykorzystania jej jako spichlerza. Po pewnym czasie kościół został zburzony ${ }^{93}$.

\section{Wołkowce}

Drewniany kościół w Wołkowcach wzniesiono w 1790 r. W latach 1821-1862 trwały parce budowlane nowej świątyni murowanej. W 1936 r. kościół został przejęty przez władze państwowe, a następnie przekształcony na dom kultury. Podczas okupacji niemieckiej kościół w Wołkowcach odzyskali wierni. W styczniu 1945 r. pełnomocnik Rady ds. kultów religijnych zarejestrował wspólnotę katolicką w Wołkowcach ${ }^{94}$. W listopadzie 1949 r. władze obwodowe przyjęły decyzję o przeznaczeniu świątyni na cele kulturalno-oświatowe. W 1950 r. wspólnota katolicka w Wołkowcach została wykreślona z rejestru. W 1951 r. w kościele

${ }^{91}$ Wońkowce, w: Stownik geograficzny, t. 13, Warszawa 1893, s. 938; Pasiecznik, Rimo-katoliczieskije obszcziny, s. 88.

${ }^{92}$ APOCh, Ispołnitielnyj komitiet Kamieniec-Podolskogo obłastnogo Sowieta dieputatow trudiaszczichsia, fund. P-338, op. 9, spr. 14, Spiec'zapiska o naliczii rimsko-katoliczieskich obszczin i namiecziajemyje mieroprijatija po otsieleniju molitwiennych domow /kostiołow, kaplic/, rospusku i sniatiju s riegistracyi obszczin etogo kulta, 28 VIII 1949, k. 78.

${ }^{93}$ APOCh, Ispołnitielnyj komitiet Kamieniec-Podolskogo obłastnogo Sowieta dieputatow trudiaszczichsia, fund. P-338, op. 15, spr. 1909, Zakluczienie, 24 X 1949, k. 126-127; APOCh, Ispołnitielnyj komitiet Kamieniec-Podolskogo obłastnogo Sowieta dieputatow trudiaszczichsia, fund. P-338, op. 15, spr. 1909, Priedsiedatelu Wierchownogo Sowieta SSSR tow. Molenkowu G. M. ot obszcziny Rimskokatoliczieskoj cerkwi Wołkowinieckogo rajona Chmielnickoj obasti USRR, 14 VIII 1954, k. 144.

${ }^{94}$ Pasiecznik, Rimo-katoliczieskije obszcziny, s. 89; APOCh, Ispołnitielnyj komitiet Kamieniec -Podolskogo obłastnogo Sowieta dieputatow trudiaszczichsia, fund. P-338, op. 9, spr. 14, Spiec'zapiska o naliczii rimsko-katoliczieskich obszczin i namiecziajemyje mieroprijatija po otsieleniju molitwiennych domow /kostiołow, kaplic/, rospusku i sniatiju s riegistracyi obszczin etogo kulta, 28 VIII 1949, k. 70. 
urządzono dom kultury ${ }^{95}$, a po pewnym zaś czasie budynek został rozebrany na cegly ${ }^{96}$.

\section{Zawalijki}

Kościół pw. św. Jana Nepomucena w Zawalijkach został ufundowany w 1815 r. W 1933 r. w świątyni urządzono na klub. W okresie okupacji niemieckiej, kościół mimo poważnych zniszczeń był wykorzystywany do kultu religijnego. W 1944 r. świątynia została wyremontowana ${ }^{97}$. Władze sowieckie odmówiły rejestracji wspólnoty katolickiej w Zawalijkach, a kościół, podobnie jak i w okresie międzywojennym, przekształciły na klub ${ }^{98}$.

\section{Zaleśce}

Drewniany kościół w Zaleścach został ufundowany w 1648 r. Murowaną świątynię wybudowano w 1791 r. Władze sowieckie w 1935 r. zamknęły kościół, a po dwóch latach rozebrały go na cegły. W czasie okupacji niemieckiej nastąpiło odrodzenie życia religijnego w Zaleścach. Miejscowi katolicy gromadzili się na nabożeństwa w domu prywatnym. W 4 czerwca 1945 r. władze radzieckie zarejestrowały wspólnotę katolicką w Zaleścach ${ }^{99}$. W 1964 r. pełnomocnik Rady ds. kultów religijnych w obwodzie chmielnickim na wniosek obwodowego komitetu wykonawczego i polecenie przełożonych z Kijowa wyrejestrował wspólnotę katolicką w Zaleścach. Pod koniec 1990 r. parafia zaleściańska została ponownie wpisana do rejestru ${ }^{100}$.

${ }^{95}$ APOCh, Ispołnitielnyj komitiet Kamieniec-Podolskogo obłastnogo Sowieta dieputatow trudiaszczichsia, fund. P-338, op. 15, spr. 1909, Zakluczienie, 30 VII 1949, k. 191-192; APOCh, Ispołnitielnyj komitiet Kamieniec-Podolskogo obłastnogo Sowieta dieputatow trudiaszczichsia, fund. P-338, op. 15, spr. 1909, Rieszenije Ispołnitielnogo Komitieta Kamieniec-Podolskogo obłastnogo Sowieta dieputatow trudiaszczichsia o pieriedaczie pomieszczienija kostioła pod Rajonnuju bibliotieku, czitalniu i lektorij, rospuskie i sniatii s riegistracyi rimsko-katoliczieskoj obszcziny w m. Wińkowcy, Wińkowieckogo rajonna, 1 IX 1949, k. 181.

${ }^{96}$ APOCh, Ispołnitielnyj komitiet Kamieniec-Podolskogo obłastnogo Sowieta dieputatow trudiaszczichsia, fund. P-338, op. 15, spr. 1909, Riedakcyi gaziety „Kołgospne seło”, 6 IX 1949, k. 140 .

${ }^{97}$ Tamże, s. 92.

${ }^{98}$ APOCh, Ispołnitielnyj komitiet Kamieniec-Podolskogo obłastnogo Sowieta dieputatow trudiaszczichsia, fund. P-338, op. 15, spr. 1909, Zakluczienie, 16 II 1951, k. 75.

${ }^{99}$ APOCh, Ispołnitielnyj komitiet Kamieniec-Podolskogo obłastnogo Sowieta dieputatow trudiaszczichsia, fund. P-338, op. 9, spr. 25, Dokładnaja zapiska ot Upołnomocziennogo Sowieta po diełam rieligioznych kultow pri Sowietie Ministrow SSSR po Kamieniec-Podolskoj obłasti, 18 VII 1953, k. 87.

${ }^{100}$ APOCh, Ispołnitielnyj komitiet Chmielnickogo obłastnogo Sowieta dieputatow trudiaszczichsia, fund. P-338, op. 21, spr. 122, Priedsiedatielu Sowieta po diełam rieligioznych kultow pri Sowietie Ministrow SSSR tow. Puzinu A.A., 7 X 1963, k. 31; APOCh, Sowiet po diełam rieligii pri Sowietie Ministrow Ukrainy. Upołnomocziennyj Sowieta po diełam religii pri Kabinietie Ministrow Ukrainy, fund. P-6416, op. 1, spr. 44, Pro rejestaraciju objednania Rymsko-katołyckoji cerkwy i peredaczu w korystuwannia wirujuczych budiwli z nastupnym pereobładnaniam jiji pid mołytownyj budynok w s. Zalisci Dunajeweckogo rajonu, 30 XI 1990, k. 278. 


\section{Zamiechów}

Drewniany kościół w Zamiechowie wzniesiono w roku 1749. W latach 18081820 wybudowano nową świątynię murowaną ${ }^{101}$. W 1935 r. kościół został przez władze sowieckie przekształcony na klub i bibliotekę. Podczas okupacji niemieckiej w kościele zaczęto ponownie odprawiać nabożeństwa. W styczniu $1945 \mathrm{r}$. obwodowy pełnomocnik Rady ds. kultów religijnych zarejestrował wspólnotę katolicką w Zamiechowie. W sierpniu natomiast część świątyni została przeznaczona na cele gospodarcze i pełniła funkcję spichlerza ${ }^{102}$. W październiku $1949 \mathrm{r}$. Obwodowy Komitet Wykonawczy zdecydował o wykorzystaniu budynku kościoła do celów oświatowo-kulturalnych, przekształcając go w siedzibę klubu i biblioteki. W lutym 1950 r. wspólnota katolicka w Zamiechowie została pozbawiona rejestracji ${ }^{103}$.

\section{Zińków}

Fundacja drewnianego kościoła w Zińkowie datuje się na 1450 r. Świątynia murowana powstała w 1750 r. ${ }^{104}$ Sowieci w 1934 r. przekształcili kościół na spichlerz. Podczas okupacji niemieckiej w częściowo zniszczonym kościele ponownie odprawiano nabożeństwa. W styczniu 1945 r. Rada ds. kultów religijnych zarejestrowała wspólnotę katolicką w Zińkowie. W marcu 1951 r. Obwodowy Komitet Wykonawczy, pod pretekstem złego stanu budynku kościoła, podjął decyzję o rozwiązaniu wspólnoty katolickiej i zamknięciu świątyni ${ }^{105}$.

\section{Zińkowce}

Kościół pw. Podwyższenia Krzyża Św. w Zińkowcach został wzniesiony w 1696 r. Władze sowieckie przekształciły go w 1930 r. na dom kultury ${ }^{106}$. W czasie II wojny światowej wierni odzyskali świątynię. W styczniu 1945 r., w odpowiedzi na wniosek wiernych, władze radzieckie zdecydowały się zarejestrować wspólnotę katolicką w Zińkowcach ${ }^{107}$. Latem 1950 r. Obwodowy Komitet Wykonawczy zamkną kościół i przeznaczył go na potrzeby kulturalno-oświatowe, urzą-

${ }^{101}$ Zamiechów, w: Stownik geograficzny, t. 14, Warszawa 1895, s. 369.

${ }^{102}$ APOCh, Ispołnitielnyj komitiet Kamieniec-Podolskogo obłastnogo Sowieta dieputatow trudiaszczichsia, fund. P-338, op. 9, spr. 14, Spiec'zapiska o naliczii rimsko-katoliczieskich obszczin i namiecziajemyje mieroprijatija po otsieleniju molitwiennych domow /kostiołow, kaplic/, rospusku i sniatiju s riegistracyi obszczin etogo kulta, 28 VIII 1949, k. 90.

${ }^{103}$ Pasiecznik, Rimo-katoliczieskije obszcziny, s. 93.

${ }^{104}$ Zińków, w: Słownik geograficzny, t. 14, Warszawa 1895, s. 620; O. Pasiecznik, Rimo-katoliczieskije obszcziny, s. 93.

${ }^{105}$ APOCh, Ispołnitielnyj komitiet Kamieniec-Podolskogo obłastnogo Sowieta dieputatow trudiaszczichsia, fund. P-338, op. 15, spr. 1909, Zakluczienie, 29 III 1951, k. 251-252.

${ }^{106}$ Zińkowce, w: Stownik geograficzny, t. 14, Warszawa 1895, s. 622; O. Pasiecznik, Rimo-katoliczieskije obszcziny, s. 94.

${ }^{107}$ APOCh, Ispołnitielnyj komitiet Kamieniec-Podolskogo obłastnogo Sowieta dieputatow trudiaszczichsia, fund. P-338, op. 9, spr. 14, Spiec'zapiska o naliczii rimsko-katoliczieskich obszczin i namiecziajemyje mieroprijatija po otsieleniju molitwiennych domow /kostiołow, kaplic/, rospusku i sniatiju s riegistracyi obszczin etogo kulta, 28 VIII 1949, k. 81. 
dzając w nim dom kultury i bibliotekę. W 1951 r. wspólnota katolicka została wykreślona z rejestru ${ }^{108}$.

$* * * * *$

Likwidacja obiektów sakralnych stanowiła jedno z podstawowych kierunków radzieckiej polityki wyznaniowej. Akcja zamykania świątyń rozpoczęta przez władze sowieckie na przełomie lat 1946-1947, podobnie jak w okresie międzywojennym, uzasadniana była koniecznością zwalczania przeżytków religijnych oraz szerzenia kultury i postępu człowieka. Zachowując pozory państwa prawa, władze starały się każde swoje przedsięwzięcie oprzeć na ustawodawstwie ZSRR, stąd też decyzje w sprawie zamknięcia świątyń argumentowano zazwyczaj niewielką liczbą wiernych, brakiem stałego duszpasterza, zbyt małą odległością świątyni od innych kościołów, złym stanem technicznym budynków itp.

Według planów sowieckich władz wyznaniowych na początku lat 50. XX wieku w obwodzie kamieniecko-podolskim miały funkcjonować wyłącznie te wspólnoty katolickie, które posiadały stałego duszpasterza, czyli dwie parafie: w Gródku Podolskim i Połonnem ${ }^{109}$. W pozostałych miejscowościach świątynie katolickie musiały być zamknięte, a wspólnoty rozwiązane. I chociaż dzięki oporowi wiernych przedsięwzięcie to nie zostało całkowicie zrealizowane, liczba wspólnot katolickich i funkcjonujących kościołów gwałtownie spadała. W $1964 \mathrm{r}$. z ponad 30 zarejestrowanych po wojnie wspólnot katolickich w obwodzie pozostało jedynie 11. Były to parafie w: Gródku Podolskim, Gołuzubińcach, Mińkowcach, Manikowcach, Podleśnym Mukarowie, Derażni, Kitajgrodzie, Latyczowie, Strudze, Greczanach i Połonnem ${ }^{110}$.

W zależności od sytuacji w poszczególnych regionach zamknięte kościoły przeznaczane były na cele kulturalno-oświatowe, gospodarcze, nierzadko też dewastowane. W świątyniach przejętych przez władze państwowe, natychmiast demontowano krzyże. By zatrzeć sakralny charakter budynków, rozbierano wieże kościelne i deformowano fasady ${ }^{111}$.

${ }^{108}$ APOCh, Ispołnitielnyj komitiet Kamieniec-Podolskogo obłastnogo Sowieta dieputatow trudiaszczichsia, fund. P-338, op. 15, spr. 1919, Upołnomocziennomu Sowieta po diełam rieligioznych kultow pri Sowietie Ministrow SSSR po Kamieniec-Podolskoj obłasti ot obszcziny s. Zińkowcy Kamieniec-Podolskogo rajona, Kamieniec-Podolskoj obasti, brak daty, k. 159; APOCh, Ispołnitielnyj komitiet Kamieniec-Podolskogo obłastnogo Sowieta dieputatow trudiaszczichsia, fund. P-338, op. 15, spr. 1919, Protokoł nr 16 zasidannia wykonkomu Zińkoweckoji silskoji Rady deputatiw trudiaszczych Kamjanec-Podilskogo rajona, 26 VIII 1949, k. 211-212; APOCh, Ispołnitielnyj komitiet Kamieniec-Podolskogo obłastnogo Sowieta dieputatow trudiaszczichsia, fund. P-338, op. 15, spr. 1919, Riszenia Wykonkomu Kamianec-Podilskoji rajonnoji Rady deputatiw trudiaszczych, 8 IX 1949, k. 352; APOCh, Ispołnitielnyj komitiet Kamieniec-Podolskogo obłastnogo Sowieta dieputatow trudiaszczichsia, fund. P-338, op. 15, spr. 1919, Zakluczienije, 4 VI 1950, k. 215-216.

${ }^{109}$ Pasiecznik, Rimo-katoliczieskije obszcziny, s. 112-113.

${ }^{110}$ APOCh, Ispołnitielnyj komitiet Chmielnickogo obłastnogo Sowieta dieputatow trudiaszczichsia, fund. P-338, op. 9, spr. 49, Swiedienija o zariegistrirowanych rieligioznych obszcziestwach w Chmielnickoj obłasti na 1 janwaria 1962 goda, 1 I 1962, k. 37-40.

${ }^{111}$ Dzwonkowski, Z historii Kościoła katolickiego w ZSRS 1917-1991, s. 271-272. 
Kościoły stanowiły dla wiernych miejsce święte, uczuciowo bardzo drogie, symbol nadziei na lepszą przyszłość, dlatego na wszelki możliwy sposób starali się bronić swoich świątyń. Zdawali sobie sprawę, że podejmując się obrony kościołów, narażali się na różnego rodzaju szykany, a nawet represje ${ }^{112}$. Znamienny jest tu przykład Gródka Podolskiego. Po zakończeniu II wojny światowej władze państwowe postanowiły zamknąć małą kapliczkę cmentarną, argumentując to brakiem księdza. Kilkutysięczna katolicka społeczność polska całodobowo czuwała przy świątyni, aż władza nie odstąpiła od swoich zamiarów. Kolejną próbę zamknięcia kaplicy podjęto za rządów Chruszczowa. Wystarczającym pretekstem do tego byłoby niewielkie uszkodzenie budynku przez nieznanych sprawców. Również wtedy wierni pilnowali kaplicy z widłami i kijami w ręku, aż do czasu wycofania się władz ze swoich planów. Skuteczna obrona kaplicy przyczyniła się do większej integracji miejscowej ludności katolickiej i wzmocniła ją moralnie na dalszą walkę ${ }^{113}$.

W podobny sposób broniono kaplicy w Tynnej, w której wierni gromadzili się po zamknięciu kościoła. Władze państwowe kilkakrotnie podejmowały próby dewastacji świątyni. Miejscowi katolicy stworzyli system alarmowy, dzięki któremu, gdy zauważono jadące w kierunku kaplicy maszyny budowlane, natychmiast pojawiał się tłum wiernych, który otaczał kaplicę żywym łańcuchem i głośno odmawiał modlitwy ${ }^{114}$.

Inną formą obrony świątyń było wysłanie delegacji wiernych do urzędów państwowych różnego szczebla: obwodowych, republikańskich, ogólnozwiązkowych. Delegacje zawoziły ponawiane wciąż petycje, podpisywane przez wiernych w starszym wieku. Prosząc o pozostawienie bądź zwrot kościoła, powoływali się na swoją wieloletnią, ciężką i ofiarną pracę w kołchozach, na swój podeszły wiek, argumentując, że świątynia służy jedynie zaspokajaniu potrzeb religijnych tylko najstarszego pokolenia. Dla wzmocnienia ważności podania pisali o swoich dzieciach, które poległy podczas „wojny ojczyźnianej”. Dzięki temu argumentowi liczyli na wysłuchanie ich próśb przez najwyższe władze państwo$w^{115}$. Petycje te były jednak przez urzędników ignorowane. Mimo to katolicy nie ustawali w walce o odzyskanie swoich kościołów. Ciągle zwracali się do najwyższych władz, ufając, że wieloletnie starania o zamknięte świątynie zostaną zwieńczone w końcu sukcesem ${ }^{116}$.

\footnotetext{
${ }^{112}$ Tamże, s. 271-272.

${ }^{113}$ Tamże, s. 272; tenże, Za wschodnia granica, s. 222.

${ }^{114}$ Słobodian, Korotkyj istorycznyj oglad, s. 324.

${ }^{115}$ Dzwonkowski, Z historii Kościoła katolickiego w ZSRS 1917-1991, s. 273.

${ }^{116}$ Szymański, Kościót katolicki na Podolu, s. 423.
} 


\section{Mapa obwodu kamieniecko-podolskiego (chmielnickiego)}

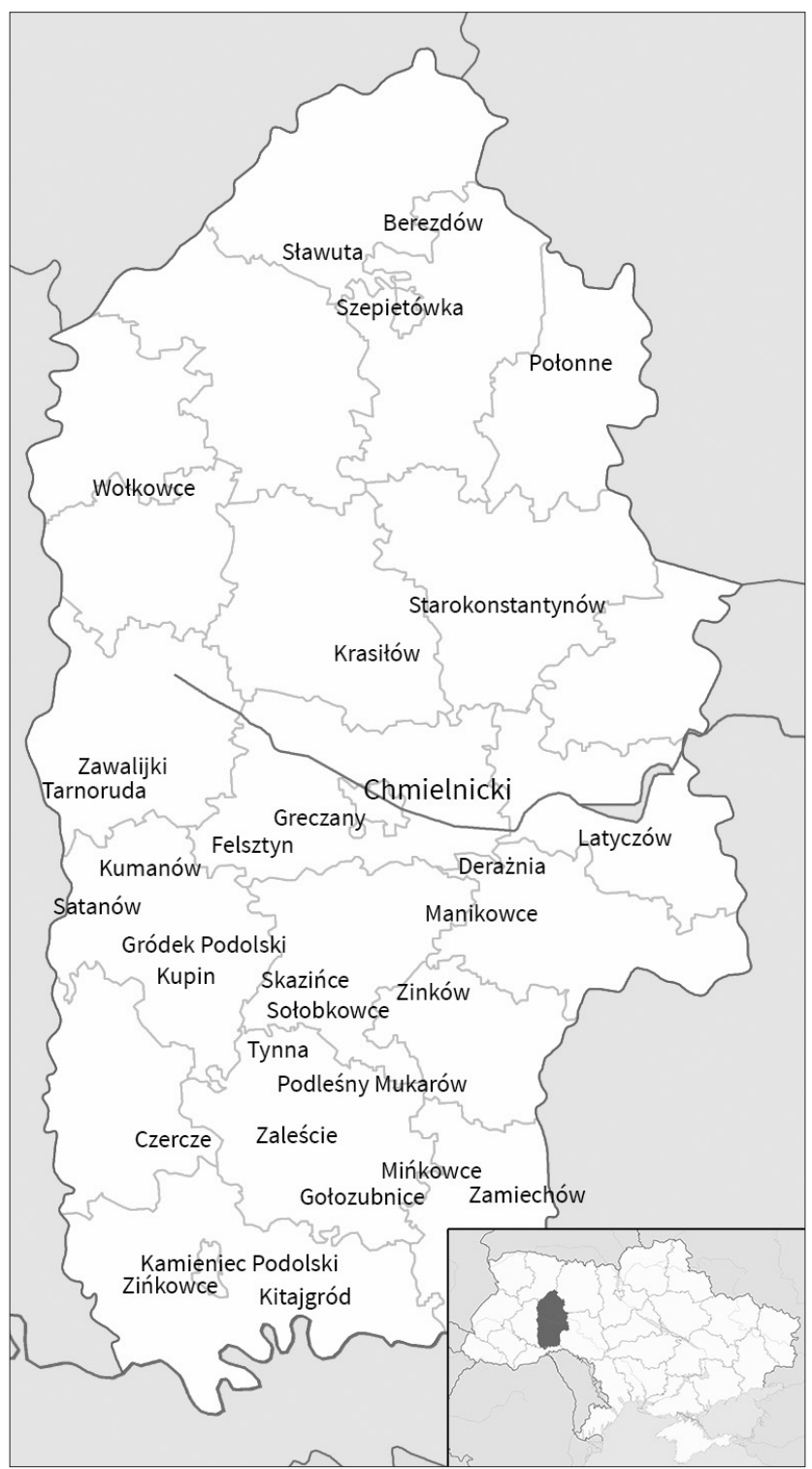

Opracowanie własne na podstawie mapy konturowej: https://upload.wikimedia.org/wikipedia/ commons/thumb/9/97/Khmelnytsky_province_location_map.svg/658px-Khmelnytsky_province_ location_map.svg.png. 


\section{REFERENCES / BIBLIOGRAFIA}

\section{Źródła}

Archiwum Państwowe Obwodu Chmielnickiego

fund. 685 - Podolskie Rzymskokatolickie Konsystorium Duchowne.

fund. P-338 - Komitet Wykonawczy kamieniecko-podolskiej (chmielnickiej) Obwodowej Rady Deputowanych Pracujących.

fund. P-6416 - Rada ds. religii przy Radzie Ministrów Ukrainy.

Archiwum Państwowe Obwodu Iwano-Frankowskiego

fund. P-388 - Pełnomocnik Rady ds. kultów religijnych przy Komitecie Wykonawczym Iwano-Frankowskiej Rady Deputowanych Pracujących.

Centralne Archiwum Państwowe Społecznych Organizacji Ukrainy

fund. 1 - Komitet Centralny Komunistycznej Partii Ukrainy.

\section{Opracowania}

Antkiewicz Zofia, Satanów, w: Miasta wielu religii. Topografia sakralna ziem wschodnich dawnej Rzeczypospolitej, red. M. Jakubowski, M. Sas, F. Walczyna, Warszawa 2016, s. $125-128$.

Bania Zbigniew, Wiraszka Marta, Kamieniec Podolski. Miasto - legenda. Zarys dziejów urbanistyki $i$ architektury od czasów najdawniejszych do współczesności, Warszawa 2001.

Biletska Mariia, Ks. Władystaw Wanags MIC i jego postuga na Podolu w latach 19772001, „Archiwa, Biblioteki i Muzea Kościelne”, 107 (2017) s. 33-62.

Berezdów, w: Słownik geograficzny Królestwa Polskiego i innych krajów słowiańskich, red. F. Sulimierski, B. Chlebowski, W. Walewski, t. 1, Warszawa 1880, s. 141.

Czercze, w: Słownik geograficzny Królestwa Polskiego i innych krajów słowiańskich, red. F. Sulimierski, B. Chlebowski, W. Walewski, t. 1, Warszawa 1880, s. 797.

Dzwonkowski Roman, Losy duchowieństwa katolickiego w ZSSR 1917-1939. Martyrologium, Lublin 1998.

Dzwonkowski Roman, Religia i Kościół katolicki w ZSRS oraz w krajach i na ziemiach okupowanych 1917-1991: kronika, Lublin 2010.

Dzwonkowski Roman, Za wschodnią granica 1917-1993. O Polakach i Kościele w dawnym ZSRR z Romanem Dzwonkowskim rozmawia Jan Pałyga, Warszawa 1993.

Dzwonkowski Roman, Z historii Kościoła katolickiego w ZSRS 1917-1991: pogadanki w Radiu Watykańskim, Ząbki 2005.

Iwanicki Karol, Katedra w Kamieńcu, Warszawa 1930.

Kamieniec Podolski, w: Słownik geograficzny Królestwa Polskiego i innych krajów słowiańskich, red. F. Sulimierski, B. Chlebowski, W. Walewski, t. 3, Warszawa 1882, s. 759 .

Kitajgód, w: Słownik geograficzny Królestwa Polskiego i innych krajów słowiańskich, red. F. Sulimierski, B. Chlebowski, W. Walewski, t. 4, Warszawa 1883, s. 115.

Kołodziejczyk Dariusz, Podole pod panowaniem tureckim. Ejalet kamieniecki 1672 1699, Warszawa 1994.

Kołybanie, w: Słownik geograficzny Królestwa Polskiego i innych krajów słowiańskich, red. F. Sulimierski, B. Chlebowski, W. Walewski, t. 4, Warszawa 1883, s. 296. 
Kopczyński Jakub, Kamieniec Podolski, w: Miasta wielu religii. Topografia sakralna ziem wschodnich dawnej Rzeczypospolitej, red. M. Jakubowski, M. Sas, F. Walczyna, Warszawa 2016, s. 74-91.

Krasiłow, w: Słownik geograficzny Królestwa Polskiego i innych krajów słowiańskich, red. F. Sulimierski, B. Chlebowski, W. Walewski, t. 4, Warszawa 1883, s. 615.

Król-Mazur Renata, Miasto trzech nacji. Studia z dziejów Kamieńca Podolskiego w XVIII wieku, Kraków 2008.

Kupin, w: Słownik geograficzny Królestwa Polskiego i innych krajów słowiańskich, red. F. Sulimierski, B. Chlebowski, W. Walewski, t. 4, Warszawa 1883, s. 886.

Latyczów, w: Słownik geograficzny Królestwa Polskiego i innych krajów słowiańskich, red. F. Sulimierski, B. Chlebowski, W. Walewski, t. 5, Warszawa 1884, s. 99-100.

Łysenko Ołeksandr, Derżawa i religijni konfesiji w Ukrajini (1943-1945), w: Aktualni probłemy witczyznianoji istorii XX st. Zbirnyk naukowych prac pryswiaczenyj pamjati akad. NAN Ukrajiny Jurija Jurijowycza Kondufora, t. 2, Kijów 2004, s. 155-209.

Mińkowce, w: Słownik geograficzny Królestwa Polskiego i innych krajów słowiańskich, red. F. Sulimierski, B. Chlebowski, W. Walewski, t. 6, Warszawa 1885, s. 448.

Nowicka Lilija, Istorycznymy steżkamy ridnogo mista, Łetycziw 2012.

Osadczyj Wołodymyr, Katołycka Cerkwa w Ukrajini. Istorycznyj narys, Lublin 2001.

Osadczy Włodzimierz, Kościół katolicki na Ukrainie wobec represji sowieckich, w: Represje wobec Kościoła w krajach Bloku Wschodnigo. Komuniści przeciw religii po 1944 roku, red. J. Marecki, Kraków 2011, s. 83-91.

Osadczy Włodzimierz, Wierzyli wbrew nadziei. Z dziejów przetrwania Kościoła łacińskiego na Ukrainie radzieckiej w okresie powojennym, „Ethos”, (2001) nr 53-54, s. 151164.

Pasiecznik Oleg, Parafija i chram u Proskurowi do 1917 roku, „Studia Catholica Podoliae", (2012) nr 6, s. 321-345.

Pasiecznik Oleg, Rimo-katoliczieskije obszcziny w Kamieniec-Podolskoj (Chmielnickoj) obłasti USRR (1945-1953), w: Represiji proty polakiw ta inszych nacionalnostej na Podilli. Rol i misce w istoriji kraju, red. I. Jaszczuk, Chmielnicki 2016, s. 86-114.

Połonne, w: Słownik geograficzny Królestwa Polskiego i innych krajów słowiańskich, red. F. Sulimierski, B. Chlebowski, W. Walewski, t. 8, Warszawa 1887, s. 727-728.

Prusiewicz Aleksander, Kamieniec Podolski. Szkic historyczny, Kijów - Warszawa 1915.

Rosowski Witalij, Kościół katolicki na terenie Ukraińskiej Socjalistycznej Republiki Radzieckiej po 1945 r., w: Kościoty chrześcijańskie w systemach totalitarnych, red. J. Kłaczkow, W. Rozynkowski, Toruń 2012, s. 662-684.

Rożkow Władysław, Ksiądz Władysław Wanags (1931-2001) - obrońca Kościoła na Podolu, Biały Dunajec-Ostróg 2018.

Sbornik zakonow SSSR i ukazow Priezidiuma Wierchownogo Sowieta SSSR. 1938 g. - ijul 1956 g., red. J. Mandelsztam, Moskwa 1956.

Schematyzm Kamjanec-Podilskoji dijeceziji, Kamieniec-Podolski 2005.

Słobodian Witalij, Korotkyj istorycznyj oglad kultu Materi Bożoji Tyniańskoji, „Studia Catholica Podoliae", nr. 8-9 (2014-2015), s. 321-326.

Sołodkowce, w: Słownik geograficzny Królestwa Polskiego i innych krajów słowiańskich, red. F. Sulimierski, B. Chlebowski, W. Walewski, t. 11, Warszawa 1890, s. 58-59.

Starokonstantynów, w: Słownik geograficzny Królestwa Polskiego i innych krajów słowiańskich, red. F. Sulimierski, B. Chlebowski, W. Walewski, t. 11, Warszawa 1890, s. $257-259$.

Struga, w: Słownik geograficzny Królestwa Polskiego i innych krajów słowiańskich, red. F. Sulimierski, B. Chlebowski, W. Walewski, t. 11, Warszawa 1890, s. 415. 
Szarowka, w: Słownik geograficzny Królestwa Polskiego i innych krajów słowiańskich, red. F. Sulimierski, B. Chlebowski, W. Walewski, t. 11, Warszawa 1890, s. 792-793.

Szumił Halina Irena, „Nigdym ja ciebie, ludu, nie rzuciła”. Z dziejów latyczowskiej Ikony, Lublin-Sandomierz 2015.

Szumił Halina Irena, Sanktuarium Matki Bożej Latyczowskiej, Sandomierz 1994.

Szymański Józef, Kościót katolicki na Podolu. Obwód winnicki 1941-1964, Lublin 2003.

Wolińska-Wójtowicz Agnieszka, Matka Boża Latyczowska, Lublin 2014.

Wońkowce, w: Słownik geograficzny Królestwa Polskiego i innych krajów słowiańskich, red. F. Sulimierski, B. Chlebowski, W. Walewski, t. 13, Warszawa 1893, s. 938.

Zamiechów, w: Słownik geograficzny Królestwa Polskiego i innych krajów słowiańskich, red. F. Sulimierski, B. Chlebowski, W. Walewski, t. 14, Warszawa 1895, s. 369.

Zińków, w: Słownik geograficzny Królestwa Polskiego i innych krajów słowiańskich, red. F. Sulimierski, B. Chlebowski, W. Walewski, t. 14, Warszawa 1895, s. 620.

Zińkowce, w: Stownik geograficzny Królestwa Polskiego i innych krajów słowiańskich, red. F. Sulimierski, B. Chlebowski, W. Walewski, t. 14, Warszawa 1895, s. 622.

\section{Netografia}

Antoniuk Dmytro, Felsztyn na Podolu, https://kuriergalicyjski.com/rozmaitosci/3853-felsztyn-na-podolu (dostęp: 6.05.2019). 


\title{
THE FATE OF ROMAN CATHOLIC CHURCHES AND COMMUNITIES IN THE KAMYANETS-PODILSKY (KHMELNYTSKYI) REGION IN THE YEARS 1944-1964
}

\begin{abstract}
The aim of the article is to present the Soviet religious policy towards the Roman Catholic Church in the former Kamianets-Podilskyi oblast in Ukraine in the years 1944-1964, with particular emphasis on the actions of the state authorities aimed at the eradication of Catholic sacred buildings.

The action of mass shutting down of temples initiated by the Soviets at the turn of 1946-1947, although not fully implemented, brought tangible results. In the year 1964, out of over 30 Catholic churches functioning after the war, only 11 remained in the Kamianets-Podilskyi oblast (Khmelnytskyi Oblast): in Gródek Podolski, Gołuzubińce, Mynkivtsi, Manikowce, Podleśny Mukarów, Derazhnia, Kitajgród, Letychiv, Struha, Greczany and Polonne.

The reasons for shutting down churches were various: lack of a permanent priest, a small number of believers, poor technical condition of the building or too small distance of the temple from other churches. Sometimes a pretext was sufficient, e.g. the allegedly urgent need to establish a community centre, school or library. In accordance with the order of the Council Representative for Religious Cults, the rooms of the closed temples could be used only for cultural and educational purposes. In reality, however, many churches, especially in rural areas, were converted into farm warehouses.

Depending on the situation in individual regions, closed churches were intended for cultural, educational and economic purposes, and were often also devastated. In temples taken over by state authorities, crosses were immediately removed. In order to obliterate the sacred character of the buildings, church towers were also demolished and the facades were deformed.
\end{abstract}

Keywords: Religion in the USSR; Roman Catholic Church; Podolia; Catholic temples; Khmelnytskyi; Kamyanets-Podilskyi 